\title{
Las gracias presidenciales a Alberto Fujimori: un análisis desde el Derecho Internacional de los Derechos Humanos
}

\section{The Presidential Grace Granted to Alberto Fujimori: An Analysis from International Human Rights Law}

\author{
Cristina Blanco Vizarreta ${ }^{(* *)}$ \\ Pontificia Universidad Católica del Perú \\ Francisco Mamani Ortega ${ }^{(* * *)}$ \\ Instituto de Democracia y Derechos Humanos
}

Resumen: El indulto y derecho de gracia concedidos a Alberto Fujimori en diciembre de 2017, fueron ampliamente cuestionados por razones éticas, políticas y jurídicas. En el ámbito del Derecho, se presentaron argumentos que evidenciaron la arbitrariedad de la medida con normas constitucionales y legales. Este artículo se enfoca en el Derecho Internacional de los Derechos Humanos y evalúa de qué modo la medida otorgada contravino normas de esta rama del Derecho Internacional. Los principales aspectos radican en la improcedencia de las gracias presidenciales en casos de graves violaciones de derechos humanos, la incompatibilidad de la medida con derechos de los familiares de las víctimas, la inobservancia de garantías del debido proceso y, la falta de necesidad y proporcionalidad en la decisión.

Palabras clave: Gracias Presidenciales - Indulto - Derecho de Gracia - Alberto Fujimori - Derecho Internacional de los Derechos Humanos

\begin{abstract}
The pardon and right of grace granted to Alberto Fujimori in December 2017 were widely questioned for ethical, political and legal reasons. In the field of Law, the decision was widely claimed as arbitrary and contrary to constitutional and legal norms. This article focuses on International Human Rights Law and assesses how the presidential grace granted contradicts norms from this field of International Law. The authors discuss the inadmissibility of presidential graces in cases of serious human rights violations, the incompatibility of the measure with the rights of the relatives of the victims, the nonobservance of due process, and the lack of necessity and proportionality in the decision.
\end{abstract}

Key words: Presidential Grace - Presidential Pardon - Right to Pardon - Alberto Fujimori - International Law of Human Rights

(*) Nota del Editor: el artículo fue recibido el 10 de noviembre y aprobada su publicación el 22 de noviembre de 2018.

${ }^{* *}$ El presente artículo se basa en dos informes de amicus curiae: el primero (Derecho de Gracia - Caso Pativilca) fue presentado al Colegiado B de la Sala Penal Nacional y fue elaborado por IDEHPUCP, Fundación para el Debido Proceso (DPLF) y Human Rights Research and Education Centre de la Universidad de Ottawa; y, el segundo (Estándares del Derecho Constitucional peruano y del Derecho Internacional sobre la obligación de combatir la impunidad frente a crímenes de lesa humanidad) fue presentado a la Corte Interamericana de Derechos Humanos y fue elaborado por IDEHPUCP, DPLF, Human Rights Research and Education Centre de la Universidad de Ottawa, Clinique international de défense des droits humains de la Universidad de Québec, Abogados sin Fronteras Canadá y Comisión Internacional de Juristas.

${ }^{* * *}$ Abogada y magíster en Derechos Humanos por la Pontificia Universidad Católica del Perú (PUCP), Lima, Perú. Investigadora principal del Instituto de Democracia y Derechos Humanos de la PUCP (IDEHPUCP) y profesora del Departamento Académico de Derecho de la PUCP. Correo electrónico: cblanco@pucp.pe.

${ }^{(* * *}$ Bachiller en Derecho por la PUCP. Asistente de investigación del IDEHPUCP. Correo electrónico: bfmamani@pucp.pe. 


\section{Introducción}

El 24 de diciembre de 2017 el ex Presidente Pedro Pablo Kuczynski concedió el indulto y derecho de gracia por razones humanitarias a Alberto Fujimori a través de la Resolución Suprema No. 281-2017-JUS. Para entonces, Fujimori había cumplido 10 de los 25 años de cárcel a los que fue condenado por la Sala Penal Nacional el 7 de abril de 2009. Dicho fallo lo encontró penalmente responsable, como autor mediato, de los delitos de asesinato, lesiones graves y secuestro agravado en los casos Barrios Altos, La Cantuta y Sótanos del Servicio de Inteligencia del Ejército (en adelante, "SIE"). Para ese mismo momento, Fujimori también era parte de un proceso penal en etapa de instrucción desde junio de 2017 en el caso Pativilca, por los delitos de asociación ilícita para delinquir y homicidio calificado. Los hechos de los casos Barrios Altos, La Cantuta y Pativilca se refieren a la ejecución extrajudicial y desaparición forzada de personas por parte del Grupo Colina durante los primeros años de la década de los noventa.

La concesión del indulto y derecho de gracia a Fujimori causó un importante rechazo a nivel nacional por considerarla un acuerdo político que aseguraba a Kuczynski la permanencia en el cargo a cambio de la libertad de Fujimori(1). Las reacciones adversas vinieron también de órganos y expertos internacionales en el seno de la Organización de las Naciones Unidas (en adelante, "ONU") y la Organización de Estados Americanos (en adelante, "OEA")(2), quienes consideraron que una medida como tal debía emitirse de forma compatible con normas internacionales de derechos humanos.

En el ámbito judicial la medida también tuvo consecuencias importantes. En cuanto a los casos Barrios Altos y La Cantuta, la Corte Interamericana tomó conocimiento del indulto y debió determinar si era compatible con lo ordenado en sus sentencias, ambas en etapa de supervisión de cumplimiento. En el caso Pativilca, el Colegiado B de la Sala Penal Nacional debió decidir si correspondía aplicar la Resolución Suprema No. 281-2017-JUS y con ello excluir a Fujimori del proceso penal. La complejidad de la escena política y alta sensibilidad del asunto, no hacían de esta sea una tarea fácil.
Este contexto llevó a que académicos y especialistas en derechos humanos, pertenecientes a diversas instituciones y organizaciones del ámbito nacional e internacional, decidiéramos presentar informes de amicus curiae ante tales instancias. La tradición jurídica conocida como amicus curiae se remonta al Derecho Romano. Su significado literal (amigo de la corte) denota el propósito para el cual fue concebido: proporcionar subsidios sobre los hechos o de iure a un tribunal, para una mejor solución de una controversia(3). En este asunto, el objetivo central fue brindar herramientas jurídicas propias del Derecho constitucional e internacional, que contribuyeran a que el Colegiado B de la Sala Penal Nacional y la Corte Interamericana de Derechos Humanos resuelvan con base en criterios técnicos, alejados del terreno político.

El presente artículo, basado en las secciones elaboradas por los autores para tales informes jurídicos, se propone compartir la visión planteada sobre la medida y contrastarla, en lo pertinente, con lo resuelto por ambas instancias. Para ello, en primer lugar, se brinda una aproximación al contexto en el que se concedió el indulto y derecho de gracia al exmandatario. Posteriormente, se analizan los que consideramos los principales cuestionamientos a la medida desde el Derecho Internacional de los Derechos Humanos (en adelante, "DIDH"). Se presentan, por último, algunas reflexiones finales de este análisis.

\section{Antecedentes y contexto de la medida}

La concesión del indulto y derecho de gracia a favor de Alberto Fujimori se realizó en un

(1) Autoridades del Poder Ejecutivo y Legislativo renunciaron a sus cargos en expresión de desaprobación, mientras que numerosos actores y partidos políticos calificaron la decisión como un acuerdo político. La Defensoría del Pueblo se pronunció de manera similar en un informe defensorial.

Defensoría del Pueblo. Indulto y derecho de gracia otorgados al expresidente Alberto Fujimori: evaluación normativa y jurisprudencial. Informe Defensorial No. 177 (Lima: Defensoría del Pueblo, 2018), 28-30.

Por su parte, organizaciones de la sociedad civil se movilizaron y cuestionaron la decisión al calificarla como ilegal y carente de objetividad. (2) Véase:

ACNUDH, "Perú: ACNUDH lamenta indulto concedido a Alberto Fujimori", Portal de ACNUDH, https://goo.gl/r4Jgrf (consultada el 25 de agosto de 2018).

Redacción Infobae, "La ONU afirmó que el indulto a Alberto Fujimori es 'una bofetada' para las víctimas de violaciones a los derechos humanos en Perú", Infobae, https://goo.gl/Ab6Sxk (consultada el 25 de agosto de 2018).

$\mathrm{CIDH}$, "Comunicado de Prensa No. 218/17: CIDH expresa profunda preocupación y cuestiona el indulto concedido a Alberto Fujimori", Portal de CIDH, https://goo.gl/C61BQy (consultada el 25 de agosto de 2018)

Redacción La República, "Secretario general de OEA comparte preocupación de CIDH por indulto a Fujimori", La República, sección Política, https://goo.gl/UPWdMh (consultada el 25 de agosto de 2018).

(3) Judithanne Scourfield McLauchlan. Congressional Participation As Amicus Curiae Before the U.S. Supreme Court (Ann Arbor: LFB Scholarly Publishing 2005, 266) 
escenario de alta tensión política entre el Poder Legislativo, con mayoría de oposición fujimorista y el Poder Ejecutivo, con Pedro Pablo Kuczynski a la cabeza. En 2016, la Operación Lava Jato reveló que la constructora brasileña Odebrecht habría realizado sobornos a funcionarios de doce países, entre ellos, Perú. En ese marco, el Congreso de la República aprobó la creación de la Comisión Lava Jato ${ }^{(4)}$, a fin de investigar presuntos actos de corrupción entre funcionarios públicos peruanos y empresas brasileñas. El 4 de diciembre de 2017, luego de que la referida Comisión manifestara su intención de citar al entonces Presidente, este señaló que no estaba obligado a comparecer y cualquier comunicación la haría por escrito ${ }^{(5)}$. No obstante, cambió de parecer cuando el 13 de diciembre del mismo año se revelaron presuntos vínculos de este con Odebretch por casos de corrupción ${ }^{(6)}$, lo que originó una solicitud de vacancia contra Kuczynski, votada en la jornada del 21 de diciembre con resultado negativo.

Como es de conocimiento público, diez congresistas de Fuerza Popular - bancada promotora de la vacancia- se abstuvieron de votar a favor de la misma, entre ellos, Kenji Fujimori(7). En semanas posteriores, se calificó esta decisión como un pacto político clandestino entre el Presidente y el entonces Congresista, dado que se revelaron conversaciones y acuerdos por parte de las personas implicadas para no apoyar la vacancia a cambio de la liberación de Fujimori.

De forma paralela, el 11 de diciembre del mismo año, Alberto Fujimori presentó una solicitud de gracias presidenciales por razones humanitarias al Instituto Nacional Penitenciario del Perú (en adelante, "INPE"), la cual fue remitida siete días después a la Secretaría Técnica de la Comisión de Gracias Presidenciales. La Junta Médica Penitenciaria que recomendó el indulto por razones humanitarias estaba integrada, entre otros, por el médico de confianza del exmandatario(8). A diferencia de otras ocasiones, esta solicitud no fue anunciada por la familia Fujimori, ni informada por el Ministerio de Justicia y Derechos Humanos (en adelante, "MINJUS") a la opinión pública(9).

Tres días después de la votación sobre la vacancia, la Comisión de Gracias Presidenciales elevó la recomendación de conceder el indulto y derecho de gracia por razones humanitarias, al considerar que el exmandatario padecía una "enfermedad no terminal grave, que se encuentra en etapa avanzada, progresiva, degenerativa e incurable; y además que las condiciones carcelarias puedan colocar en grave riesgo su vida, salud e integridad"(10). Con base en ello, Kuczynski, a las 18:00 horas del 24 de diciembre, concedió a Alberto Fujimori el "indulto y derecho de gracia por razones humanitarias", mediante Resolución Suprema No. 281-2017-JUS ${ }^{(11)}$, publicada en una edición extraordinaria del diario oficial El Peruano.

Pero ¿cuál era la situación jurídica del exmandatario al momento del otorgamiento de la medida? En primer lugar, el caso Barrios Altos se remonta al 3 de noviembre de 1991, cuando el Grupo Colina ejecutó extrajudicialmente a quince personas -entre ellas, un niño de ocho años- en una vivienda del jirón Huanta, donde se realizaba una pollada. El caso La Cantuta se refiere a los hechos ocurridos el 18 de julio de 1992, fecha en que el Grupo Colina ejecutó a nueve estudiantes y un profesor de la Universidad Nacional de Educación Enrique Guzmán La Valle, conocida como La Cantuta. En virtud de los hechos ocurridos, la Corte IDH emitió una sentencia en 2001 (caso Barrios Altos) y otra en 2007 (caso La Cantuta)(12), en las cuales resolvió, entre otros, la responsabilidad del Estado peruano y el deber de investigar los hechos para determinar a las personas responsables de las violaciones de derechos humanos. En ese marco, los juicios contra el expresidente Alberto Fujimori iniciaron el 10 de diciembre de 2007, luego de que la Corte Suprema de Justicia de Chile autorizara su

(4) Comisión Especial Multipartidaria encargada de Investigar los Presuntos Sobornos, Coimas y Dádivas que hubieran recibido funcionarios públicos de los diferentes niveles de gobierno, en relación a las concesiones, obras y proyectos que hayan sido adjudicados a las empresas brasileñas Odebrecht, Camargo Correa, OAS, Andrade Gutiérrez, Queiroz Galvao y otras, desde el inicio de sus actividades hasta la fecha por cualquier forma de contratación con el Estado peruano.

(5) Redacción Gestión, "PPK: No estoy obligado a comparecer ante Comisión Lava Jato”, Diario Gestión, 4 de diciembre de 2017, sección Política, https://goo.gl/naD48Y (consultada el 25 de agosto de 2018).

(6) Redacción El Comercio, "PPK aceptó reunirse con la Comisión Lava Jato del Congreso", Diario El Comercio, 14 de diciembre de 2017 sección Política, https://goo.gl/1DDtji (consultada el 25 de agosto de 2018).

(7) Hijo de Alberto Fujimori y, en ese momento, Congresista de la República por Fuerza Popular.

(8) Ernesto Cabral, “Doctor de Alberto Fujimori integra junta médica penitenciaria que pidió el indulto”, OjoPúblico, 23 de diciembre de 2017, sección Actualidad, https://goo.gl/BYgmdR (consultada el 26 de agosto de 2018).

(9) Jonathan Castro y Ernesto Cabral, "La estrategia secreta del indulto: Los últimos días de Fujimori en la cárcel”, OjoPúblico, 28 de diciembre de 2017, sección Actualidad, https://goo.gl/RFKSCz (consultada el 26 de agosto de 2018).

(10) Consideraciones de la Resolución Suprema No. 281-2017-JUS, publicada el 24 de diciembre de 2017 en el diario oficial El Peruano.

(11) Artículo $1^{\circ}$ de la Resolución Suprema No. 281-2017-JUS.

(12) Corte IDH, Caso Barrios Altos vs. Perú. Fondo, Sentencia de 14 de marzo de 2001, Serie C, No. 75; Caso La Cantuta vs. Perú. Fondo, Reparaciones y Costas. Sentencia de 29 de noviembre de 2006. Serie C, No. 162. 


\section{Las gracias presidenciales a Alberto Fujimori: un análisis desde el Derecho Internacional de los Derechos Humanos}

extradición a solicitud del Estado peruano por los casos Barrios Altos, La Cantuta y otros ${ }^{(13)}$.

Dos años después de iniciar el proceso penal, el 7 de diciembre de 2009, la Sala Penal Especial de la Corte Suprema emitió una sentencia en la que declaró a Alberto Fujimori como autor mediato de los delitos de homicidio y lesiones graves por ambos casos. Dicha Sala señaló que tales delitos "constituyen crímenes contra la Humanidad según el Derecho Internacional Penal"(14). Igualmente, Fujimori fue encontrado responsable de secuestro agravado en agravio de Gustavo Gorriti y Samuel Dyer (caso Sótanos del SIE).

En virtud a ello, fue condenado a veinticinco años de pena privativa de libertad. Tal condena, que concluiría el 10 febrero de 2032, llevaba diez años cumplidos a la fecha del indulto. También se ordenó el pago de una reparación civil(15), aún no cancelada. La defensa legal de Alberto Fujimori cuestionó este fallo mediante un recurso de nulidad que fue desestimado ${ }^{(16)}$. Posteriormente, el exmandatario procuró su liberación a través de varias acciones ${ }^{(17)}$.

Dado que Alberto Fujimori fue entregado al Perú en calidad de extraditado, mediante sentencia de la Corte Suprema de Justicia de Chile en 2007, solo podía ser juzgado en nuestro país por los casos autorizados ${ }^{(18)}$. En el 2015 , se remitió una solicitud de ampliación de extradición a dicho Tribunal, la misma que fue aprobada el 5 de junio de 2017 por los delitos de asociación ilícita para delinquir y homicidio calificado respecto al caso Pativilca. Los hechos de este caso ocurrieron el 29 de enero de 1992, cuando el Grupo Colina habría ejecutado a seis campesinos de la Pampa
San José y Caraqueño del distrito de Pativilca. En la sentencia que amplió la extradición, la justicia chilena calificó estos hechos como "una violación grave y manifiesta de los derechos y libertades proclamadas en la Declaración Universal de los Derechos Humanos", así como "crímenes de lesa humanidad"(19). Actualmente, este caso se encuentra en etapa oral.

La referida Resolución Suprema concedió tanto indulto como derecho de gracia a Alberto Fujimori. Ambas figuras son consideradas gracias presidenciales, contempladas en la Constitución Política como potestades del Presidente de la República ${ }^{(20)}$, pero se trata de figuras distintas. Mientras que el indulto se refiere a "la renuncia al ejercicio del poder punitivo del Estado respecto de los condenados", el derecho de gracia consiste en "extinguir la acción penal a los procesados en los casos en que la etapa de instrucción haya excedido el doble de su plazo más su ampliatoria"(21). Es por esto que el indulto tendría efectos en los casos por los que Alberto Fujimori se encontraba condenado (casos Barrios Altos, Cantuta y sótanos del SIE); mientras que el derecho de gracia, en los procesos penales sin sentencia firme (caso Pativilca).

(13) Además de los casos Barrios Altos y La Cantuta, la Corte Suprema de Chile aprobó la extradición por los siguientes casos: Sótanos del Servicio de Inteligencia del Ejército, Congresistas tránsfugas, Allanamiento, Interceptación telefónica, 15 millones, Tractores chinos y Medios de Comunicación. Carolina Valenzuela, “Corte Suprema resuelve extraditar a Alberto Fujimori”, Diario El Mercurio, 21 de setiembre de 2007, sección Nacional, https://goo.gl/nTEqo1 (consultada el 26 de agosto de 2018). Ronald Gamarra Herrera, "A propósito de la histórica extradición de Alberto Fujimori”, Portal Derecho Penal de la Universidad de Fribourg, 2008, https://goo.gl/a2ZY9Z (consultada el 26 de agosto de 2018).

(14) Corte Suprema de Justicia de la República. Sala Penal Especial, Sentencia recaída en el Expediente No. A.V. $19-2001$ de 7 de abril de 2009, considerandos 823-824.

(15) Corte Suprema de Justicia de la República. Sala Penal Especial, Sentencia recaída en el Expediente No. A.V. $19-2001$ de 7 de abril de 2009, considerando 825. La reparación civil hacia las víctimas asciende a 62400 soles a favor de cada hermano de las víctimas de Barrios Altos y el pago de 62000 soles a favor de los herederos legales de las víctimas de La Cantuta. Corte Suprema de Justicia de la República. Sala Penal Especial, Sentencia recaída en el Expediente No. A.V. 19-2001 de 7 de abril de 2009 , considerando 825.

(16) Corte Suprema de Justicia de la República. Primera Sala Penal Transitoria, Sentencia recaída en el Expediente No. 19-2001-09-A.V. de 30 de diciembre de 2009 , parte decisoria.

(17) Su defensa interpuso al menos cinco hábeas corpus en los años 2010, 2014, 2015 y 2017. Los cuatro primeros fueron desestimados al no acreditarse la vulneración de sus derechos fundamentales, mientras que el quinto también fue rechazado por haberse producido la sustracción de la materia, dado que el expresidente ya se encontraba en libertad.

TC, "Tribunal Constitucional rechaza hábeas corpus a favor del expresidente Alberto Fujimori Fujimori interpuesto contra las sentencias penales que lo condenaron por el delito de secuestro agravado en agravio de Gustavo Gorriti y Samuel Dyer. Nota de prensa”, Portal del TC, https://goo.gl/wm7sQK (consultada el 28 de agosto de 2018).

(18) Tratado de Extradición entre Chile y Perú; "Artículo VIII. -La extradición acordada por uno de los Gobiernos al otro, no autoriza el enjuiciamiento y castigo del extraído por delito distinto del que sirvió de fundamento a la demanda respectiva, ni la entrega a otra Nación que lo reclame. Para acumular a la causa del mismo individuo un crimen o delito anterior que se hallare comprendido entre los que dan lugar a la extradición, será necesario el consentimiento especial del Gobierno que hizo la entrega del delincuente".

(19) Corte Suprema de Justicia de Chile, Sentencia de extradición a Alberto Fujimori de 5 de junio de 2017, párrafo 4.

(20) Constitución Política del Perú. - "Artículo 118.- Corresponde al Presidente de la República: (...) 21. Conceder indultos y conmutar penas. Ejercer el derecho de gracia en beneficio de los procesados en los casos en que la etapa de instrucción haya excedido el doble de su plazo más su ampliatoria (...)".

(21) Artículo 3 del Reglamento Interno de la Comisión de Gracias Presidenciales, aprobado por Resolución Ministerial No. 0162-2010-JUS, publicada el 14 de julio de 2010 en el diario oficial El Peruano. 
En cuanto a los casos Barrios Altos y La Cantuta, dado que cuentan con sentencia de la Corte IDH en etapa de supervisión, los familiares de las víctimas y sus representantes informaron a dicha instancia sobre la medida tomada. Ello condujo a la emisión de una resolución de supervisión por parte de la Corte en la que dispuso que el Estado peruano ejerza control sobre el indulto, mediante la jurisdicción constitucional(22). En atención a ello, el 20 de julio del mismo año, los representantes de las víctimas solicitaron a la Corte Suprema de Justicia que "se ejerza el control de convencionalidad respecto a la Resolución Suprema No. 281-2017-JUS que concedió el indulto humanitario a favor de Alberto Fujimori y, como tal, se declare su nulidad"(23). El 3 de octubre se declaró que dicha Resolución carecía de efectos jurídicos para la ejecución del presente caso y, por ende, "fundado el pedido de la parte civil de no aplicación del indulto por razones humanitarias a favor del condenado"(24). Actualmente, está pendiente de resolución la apelación a este fallo por parte de la defensa legal de Fujimori.

Por otro lado, la Resolución Suprema No. 281-2017-JUS fue revisada por el Colegiado B de la Sala Penal Nacional, el cual decidió si debía aplicar o no el derecho de gracia en el caso Pativilca, dado que esta gracia presidencial excluiría a Alberto Fujimori en dicho proceso. El 19 de febrero de 2018, el Colegiado B de la Sala Penal Nacional publicó su Resolución No. 039, en la que resolvió que la mencionada Resolución Suprema "carece de efectos jurídicos para el presente caso"(25), por lo que no se aplicaría el derecho de gracia al expresidente y este seguiría siendo procesado. El Procurador Ad Hoc interpuso recurso de nulidad al considerar que el derecho de gracia fue concedido conforme a la Constitución ${ }^{(26)}$, cuestión que está pendiente de resolución a la fecha.

\section{Observaciones sobre el indulto y derecho de gracia a Alberto Fujimori}

\begin{abstract}
El artículo 118, inciso 21, de nuestra Constitución reconoce la potestad presidencial de "conceder indultos y conmutar penas. Ejercer el derecho de gracia en beneficio de los procesados en los casos en que la etapa de instrucción haya excedido el doble de su plazo más su ampliatoria". Ambas figuras han sido materia de disposiciones normativas que determinan cómo pueden ser otorgadas, su improcedencia frente a determinados delitos y los efectos de su otorgamiento ${ }^{(27)}$.
\end{abstract}

Los orígenes de las gracias presidenciales, en general, tienen una larga raigambre histórica. Se consolidan en monarquías y reinados, previos al estado democrático de derecho de fines del siglo XVIII (28). Hay quienes señalan que estas son inconstitucionales o en todo caso, tienen escasa justificación en los sistemas jurídicos contemporáneos, a menos que la sanción sea la pena de muerte ${ }^{(29)}$. Ello al considerar que, por un lado, los mismos fines se pueden conseguir a través de mecanismos judiciales y constitucionales; y de otro, atentan contra las funciones constitucionales de la pena ${ }^{(30)}$.

El Tribunal Constitucional (en adelante, "TC"), por su parte, ha reconocido que es

(22) Corte IDH, Caso Barrios Altos y Caso La Cantuta vs. Perú. Supervisión de Cumplimiento de Sentencia. Resolución de 30 de mayo de 2018, punto resolutivo 4.

(23) Petitorio del Escrito No. 01 del Expediente No. A.V. 19-2001, presentado a la Corte Suprema de Justicia de la República el 20 de julio de 2018.

(24) Corte Suprema de Justicia de la República. Juzgado Supremo de Investigación Preparatoria, Resolución No. 010 recaída en el Expediente Nº0006-2001-4-5001-SU-PE-01 de 3 de octubre de 2018, párrafos decisorios 1 y 2.

(25) Corte Suprema de Justicia de la República. Sala Penal Nacional, Resolución No. 039 recaída en el Expediente No 00649-2011-0-5001-JRPE-03 de 9 de febrero de 2018, parte resolutiva, párrafo 1.

(26) Redacción El Comercio, "Procurador ad hoc impugnó fallo sobre Caso Pativilca", Diario El Comercio, 21 de febrero de 2018 , sección Política, https://goo.gl/9XcUFS (consultada el 28 de agosto de 2018).

(27) En particular, véase (i) Decreto Supremo 004-2007-JUS del 1 de abril de 2007 que crea "la Comisión de Indulto y Derecho de Gracia por Razones Humanitarias y Conmutación de la Pena", modificado por Decreto Supremo 008-210-JUS; y (ii) Resolución Ministerial No. 01622010-JUS, Reglamento Interno de Comisión de Gracias Presidenciales. Asimismo, el artículo 78, inciso 1 del Código Penal, modificado por Ley 26993, señala que la gracia presidencial constituye una causal de extinción de la acción penal, naturaleza que comparte junto con la figura de la amnistía. Además, existen leyes que impiden que proceda el indulto (en general), conmutación de pena y derecho de gracia por delitos de secuestro y extorsión (artículo 2 de la Ley 28760); por los delitos de violación sexual de menor de edad y violación sexual de menor de edad seguida de muerte o lesión grave (artículo 2 de la Ley 28704); y por los delitos de sicariato, y conspiración y ofrecimiento para el mismo (primera disposición complementaria final del Decreto Legislativo 1181).

(28) Es una institución basada en un concepto de justicia entendida como "venganza" o "crueldad", propio de otros tiempos. Ello justificaba la posibilidad al soberano de usar una institución que permita equilibrar la justicia y aumentar su prestigio frente a sus súbditos. Como explica Bernabé, "La institución de la gracia era concebida como un atributo de la divinidad que la ejercita, y la teología la entiende '(...) como medio para equilibrar la justicia'. De la divinidad se traslada al rey, ya que éste representa a Dios en la tierra, convirtiéndose de este modo en un instrumento arbitrario en manos del Príncipe: voluntad benévola (...), capricho, favor, que acabará por caracterizar la soberanía del poder absoluto".

Bernabé I. Antecedentes históricos del indulto. Revista de Derecho UNED 10 (enero 2012): 687

(29) Alfonso Ruiz Miguel, "Gracia y justicia: el lugar de la equidad”, Revista Derecho PUCP 94 (noviembre 2017).

(30) Ricardo Nicanor Elías Puelles, "Los fines constitucionales de la pena como fundamento para la derogación de las gracias presidenciales" (tesis de licenciatura, Facultad de Derecho de la Pontificia Universidad Católica del Perú, 2011, 302). 
precisamente "dado el origen histórico del que proviene (...), que resulta necesario el establecer sus funciones y límites dentro de un estado democrático y constitucional de derecho"(31). Como ha expresado este tribunal, en un Estado constitucional y democrático como el nuestro, "dos elementos caracterizadores de este tipo de Estado son la supremacía jurídica de la Constitución y la tutela de los derechos fundamentales"(32). Ha agregado que "el Estado constitucional se caracteriza, precisamente, por limitar y controlar el ejercicio arbitrario del poder del Estado y de los particulares"(33).

En efecto, si bien tales atribuciones constitucionales son discrecionales (en la medida en que el Presidente de la República decide si la otorga o no), ello no comporta que puedan ser ejercidas de modo arbitrario. En virtud a ello, el ejercicio del indulto y derecho de gracia debe ceñirse al principio constitucional de interdicción de la arbitrariedad, expresado en el artículo 45 de la Constitución que establece que "el poder del Estado emana del pueblo. Quienes lo ejercen lo hacen con las limitaciones y responsabilidades que la Constitución y las leyes establecen"(34).

De este modo, es claro que toda autoridad o funcionario público está sometido a la Constitución, por lo que ninguna prerrogativa puede ser ejercida desconociendo principios y valores de carácter constitucional, o al margen del respeto de los derechos fundamentales. Esto mismo es exigible al Presidente de la República, máxime cuando la propia Constitución señala en el artículo 118, inciso 1, que corresponde al Presidente, "cumplir y hacer cumplir la Constitución y los tratados, leyes y demás disposiciones legales".

Se toma entonces como punto de partida que esta prerrogativa presidencial debe ser ejercida dentro de los límites que le exigen la Constitución, los tratados de los que el Perú es Estado parte y las normas legales pertinentes. Sin perjuicio de considerar que la medida presenta cuestionamientos desde el ámbito constitucional( ${ }^{(35)}$ y legal, nos enfocamos en su carácter inconvencional. Es decir, se analiza su compatibilidad con tratados de derechos humanos, en especial con la Convención Americana sobre Derechos Humanos (en adelante, "CADH") y la jurisprudencia de la Corte IDH. Desde el DIDH, pueden identificarse cuatro principales observaciones que son abordadas a continuación: (i) improcedencia de la medida por tratarse de graves violaciones de derechos humanos; (ii) incompatibilidad con relación al derecho a la verdad y a la tutela judicial efectiva; (iii) inobservancia de garantías del debido proceso; y (iv) falta de necesidad y proporcionalidad.

\section{No procede el indulto $y$ derecho de gracia frente a graves violaciones de derechos humanos}

Si bien la Corte IDH no se ha pronunciado específicamente sobre las gracias presidenciales por razones humanitarias, figura propia del ordenamiento peruano( ${ }^{(36)}$, esta cuenta con un amplio acervo jurisprudencial que le permite evaluarla a partir de las obligaciones de los Estados parte de la CADH y los estándares interamericanos. Los casos Barrios Altos, La Cantuta y Pativilca versan sobre hechos considerados como graves violaciones de derechos humanos, así como también crímenes de lesa humanidad, de acuerdo a las decisiones judiciales de los tribunales competentes. Ostentan, por tanto, una especial relevancia al atentar contra valores fundamentales que hacen parte del orden público internacional, y trascienden al ámbito particular e interno.

Cabe precisar que las graves violaciones de derechos humanos no necesariamente son crímenes de lesa humanidad. Se entiende a las primeras como conductas que violan numerosos derechos humanos inderogables o que vulneran el reconocimiento de la personalidad jurídica del ser humano ${ }^{(37)}$. Al

(31) TC. Expediente No 4053-2007-PHC/TC. fj 10.

(32) En palabras del TC, “(...) el primer elemento permite que la Constitución, en tanto norma jurídica y política suprema, establezca el marco jurídico dentro del cual se realiza el ejercicio de los poderes públicos y privados. Por su parte, la tutela de los derechos fundamentales, en tanto éstos comportan una eficacia vertical y horizontal, se erigen como auténticos límites al ejercicio del poder estatal, pero también de los particulares". TC. STC 06204-2006-HC/TC. Fj. 8.

(33) TC. STC 06204-2006-HC/TC. Fj. 8.

(34) Al respecto véase TC. STC 06204-2006-HC/TC, STC 5760-2006-AA/TC.

(35) Por ejemplo, un requisito constitucional para el derecho de gracia es "que la etapa de instrucción haya excedido el doble del plazo más su ampliatoria" (Artículo 118.22 de la Constitución Política del Perú). Dicho plazo está previsto para evitar el exceso de carcelería de los internos procesados. En el presente caso, el plazo sería de 24 meses, el cual no se habría cumplido dado a partir del 5 de junio de 2017, fecha en que la justicia chilena aprobó la ampliación de extradición, y al momento de otorgar el derecho de gracia solo habían transcurrido apenas seis meses. En ese mismo sentido se pronunció el Colegiado B de la Sala Penal Nacional y señaló que se incumplía con un requisito formal, por lo que dejó sin efecto jurídico el derecho de gracia para el caso Pativilca.

Corte Suprema de Justicia de la República. Sala Penal Nacional, Resolución No. 039 recaída en el Expediente Nº0649-2011-0-5001-JRPE-03 de 9 de febrero de 2018, parte resolutiva, párrafo 1 .

(36) Véase artículo 3 del Reglamento Interno de la Comisión de Gracias Presidenciales.

(37) Federico Andreu. "Artículo 3 Derecho al reconocimiento de la personalidad jurídica", en Convención Americana sobre Derechos Humanos comentada, coords. Steiner, Christian y Patricia Uribe (México D.F.: Suprema Corte de Justicia de la Nación y KAS, 2014), 107-108. 
respecto, la Corte IDH ha señalado que estas pueden ser "la tortura, las ejecuciones sumarias, extralegales o arbitrarias y las desapariciones forzadas, todas ellas prohibidas por contravenir derechos inderogables reconocidos por el DIDH"(38).

De otro lado, los delitos de lesa humanidad son un crimen internacional definido por el Estatuto de Roma de la Corte Penal Internacional como aquel que "se comet(e) como parte de un ataque generalizado o sistemático contra una población civil y con conocimiento de dicho ataque"(39). Si bien toda violación de una obligación internacional hace surgir la obligación de reparar el daño causado, cuando se trata de crímenes de lesa humanidad la obligación del Estado es más amplia ${ }^{(40)}$. La Corte IDH ha señalado que estos crímenes incluyen la comisión de actos inhumanos, como el asesinato, cometidos en un contexto como los señalados por el Estatuto de Roma(41). Además, debe entenderse que el conocimiento de dicho ataque es un elemento que existe si el autor tenía la intención de cometer un ataque de esa índole ${ }^{(42)}$.

En cuanto a la relación entre ambos, la Corte Interamericana ha señalado que "según el corpus iuris del Derecho Internacional, un crimen de lesa humanidad es en sí mismo una grave violación a los derechos humanos y afecta a la humanidad toda"(43). Dicho Tribunal ha calificado así las graves violaciones de derechos humanos también como crímenes de lesa humanidad sobre la base de normas jurídicas internacionales consuetudinarias y de jus cogens ${ }^{(44)}$. De este modo, hechos considerados como crímenes de lesa humanidad, pueden ser también graves violaciones de derechos humanos, como sucede en los casos bajo análisis. No necesariamente ocurre a la inversa pues deben constatarse los elementos adicionales que configuran el crimen de lesa humanidad.

En el caso Pativilca, en particular, la Corte Suprema de Chile, al conocer la solicitud de ampliación de la extradición, se pronunció en los siguientes términos:

“(...) esta Corte comparte lo afirmado por el sentenciador de primera instancia, referido al carácter de lesa humanidad de los delitos de homicidio calificado y asociación ilícita para delinquir por los cuales se requiere la ampliación de la extradición de
Alberto Fujimori Fujimori, conclusión que priva de sustento a la alegación sobre la extinción de la acción penal ejercida en la causa iniciada por denuncia No 02-2007 en el país requirente, habida cuenta que tales ilícitos merecen una reprobación tan enérgica de la conciencia universal al atentar contra los valores humanos fundamentales, que ninguna convención, pacto o norma positiva puede derogar, enervar o disimular al contravenir no solo los bienes jurídicos comúnmente garantizados por las leyes penales, sino que además suponen una negación de la personalidad del hombre. En definitiva constituyen un ultraje a la dignidad humana y representan una violación grave y manifiesta de los derechos y libertades proclamadas en la Declaración Universal de los Derechos Humanos, reafirmadas y desarrolladas en otros instrumentos internacionales pertinentes, por lo que se ha de reconocer su carácter de imprescriptibles, así como la imposibilidad de amnistiarlos y de consagrar excluyentes de responsabilidad que pretendan impedir la investigación y sanción de los responsables de tan graves violaciones a los derechos esenciales, prohibidas por el derecho internacional de los derechos humanos"(45) (énfasis propio).

De otro lado, la Corte IDH calificó los hechos ocurridos en Barrios Altos como "violaciones graves de derechos humanos"(46) y a los hechos relativos a La Cantuta, como "crímenes contra la humanidad"(47). Además, mediante resolución de supervisión de cumplimiento del caso Barrios Altos de setiembre de 2012, la Corte IDH consideró contradictoria con su fallo la Ejecutoria Suprema de la Sala Penal

(38) Corte IDH, Caso Barrios Altos vs. Perú. Fondo, Sentencia de 14 de marzo de 2001, Serie C No. 75, párrafo 41.

(39) Artículo 7.1 del Estatuto de Roma de la Corte Penal Internacional.

(40) Juan E. Méndez, "Derecho a la verdad frente a las graves violaciones a los derechos humanos", en La aplicación de los tratados sobre derechos humanos en el ámbito local, comps. Víctor Abramovich, Alberto Bovino y Christian Courtis (Buenos Aires: Editores del Puerto, 1997), 525.

(41) Corte IDH, Caso Almonacid Arellano y otros vs. Chile. Excepciones Preliminares, Fondo, Reparaciones y Costas, Sentencia de 26 de setiembre de 2006. Serie C No. 154, párrafo 96.

(42) Véase los Elementos de los Crímenes, reproducidos de Documentos Oficiales de la Asamblea de los Estados Partes en el Estatuto de Roma de la Corte Penal Internacional, primer período de sesiones, Nueva York, 3 a 10 de septiembre de 2002.

(43) Corte IDH, Caso Almonacid Arellano y otros vs. Chile. Excepciones Preliminares, Fondo, Reparaciones y Costas, Sentencia de 26 de setiembre de 2006. Serie C No. 154, párrafo 105.

(44) Burneo Labrín, José. Derecho Penal Internacional. Genealogía de los crímenes internacionales más graves (Lima: Fondo Editorial PUCP, 2017, 267).

(45) Corte Suprema de Justicia de Chile, Sentencia de extradición a Alberto Fujimori de 5 de junio de 2017.

(46) Corte IDH, Caso Barrios Altos vs. Perú. Fondo. Sentencia de 14 de marzo de 2001. Serie C No. 75 , párrafo 41.

(47) Corte IDH, Caso La Cantuta vs. Perú. Fondo, Reparaciones y Costas, Sentencia de 29 de noviembre de 2006. Serie C No. 162, párrafo 225. 
Permanente de la Corte Suprema de Justicia que, en julio de 2012, declaró que las ejecuciones extrajudiciales ocurridas por el caso Barrios Altos no constituyeron delito de lesa humanidad ${ }^{(48)}$. Al respecto, señaló que dicha Ejecutoria Suprema "entra en contradicción con lo resuelto anteriormente por la misma Corte Suprema de Justicia en el juzgamiento de otro de los involucrados en los hechos del presente caso, así como con otras decisiones nacionales, en cuanto a la calificación de los actos como crímenes de lesa humanidad según el derecho internacional"(49).

Ahora bien, la relevancia de afirmar que se trata ya sea de graves violaciones de derechos humanos y/o de crímenes de lesa humanidad, radica en la imposibilidad de adoptar medidas que impidan la aplicación de la justicia. La sentencia del caso Barrios Altos es histórica precisamente porque en ella se afirma por primera vez que:

"Son inadmisibles las disposiciones de amnistía, las disposiciones de prescripción y el establecimiento de excluyentes de responsabilidad que pretendan impedir la investigación y sanción de los responsables de las violaciones graves de los derechos humanos tales como la tortura, las ejecuciones sumarias, extralegales o arbitrarias y las desapariciones forzadas, todas ellas prohibidas por contravenir derechos inderogables reconocidos por el DIDH"(50).

Ello ha sido reiterado por dicho Tribunal en sentencias posteriores que reflejan, en general, una firme línea jurisprudencial en el sentido de considerar inadmisibles figuras que impidan la investigación, juzgamiento y sanción de los responsables de graves violaciones de derechos humanos ${ }^{(51)}$. Es cierto que, como se afirmaba constantemente, no habría jurisprudencia específica sobre indulto o el indulto humanitario ${ }^{(52)}$. Sin embargo, no cabe interpretar los excluyentes de responsabilidad como una lista cerrada, sino de manera general en atención a evitar la impunidad. Así es como la Corte Interamericana resuelve este caso, en el que la medida concedida representaba una forma de eludir el cumplimiento de una sanción penal.

Además, cabe notar que otros instrumentos internacionales expresan o sustraen implícitamente el ámbito de aplicación de los indultos a las graves violaciones de derechos humanos y crímenes de lesa humanidad. Así, por ejemplo, la Ley sobre el Establecimiento de Salas Extraordinarias en las Cortes de Camboya para el Procesamiento de Delitos Cometidos durante el Régimen de la Campuchea Democrática, adoptada bajo los auspicios de la ONU, excluye el indulto y la amnistía para los delitos de homicidio, tortura y persecución religiosa, genocidio, crímenes de lesa humanidad, violaciones graves de los Convenios de Ginebra del 12 de agosto de 1949, destrucción de bienes culturales durante conflictos armados y crímenes contra personas internacionalmente protegidas de conformidad con la Convención de Viena de 1961 sobre Relaciones Diplomáticas ${ }^{(53)}$.

En el Derecho comparado, a pesar de que la legislación sobre indulto en cada Estado presenta diferencias, se observa una tendencia común orientada a impedir su aplicación cuando se trata de graves violaciones a los derechos humanos. Estos reconocen que se trata de una prerrogativa constitucional que permite al Jefe de Gobierno o al Congreso eximir al condenado de cumplir con su sanción. A nivel legislativo, han limitado la aplicabilidad del indulto cuando se encuentran involucrados delitos que afectan derechos humanos, en coherencia con sus obligaciones internacionales ${ }^{(54)}$.

EI TC peruano también se ha valido de su jurisprudencia en materia de amnistía al referirse a la necesidad de que las gracias presidenciales sean ejercidas de modo compatible con la Constitución. Haciendo un símil con la figura de la amnistía, el máximo intérprete constitucional ha señalado que esta medida "no puede fundarse en un motivo incompatible con la Constitución"(55). Procurar que violaciones de derechos humanos queden en impunidad es altamente incompatible con la

(48) Corte Suprema de Justicia de la República. Sala Penal Permanente, R.N. № 4104-2010, Ejecutoria Suprema de 20 de julio de 2012.

(49) Corte IDH, Caso Barrios Altos vs. Perú. Supervisión de Cumplimiento de Sentencia, Resolución de 7 de septiembre de 2012 , párrafo. 48.

(50) Corte IDH, Caso Barrios Altos vs. Perú. Fondo, Sentencia de 14 de marzo de 2001. Serie C No. 75, párrafo 41; y, Caso La Cantuta vs. Perú. Fondo, Reparaciones y Costas, Sentencia de 29 de noviembre de 2006. Serie C No. 162, párrafo 152.

(51) Corte IDH, Caso Gutiérrez Soler vs. Colombia, sentencia de 12 de septiembre de 2005. Serie C No. 132, párrafo 97; y, Caso Masacres de El Mozote y lugares aledaños vs. El Salvador. Fondo, Reparaciones y Costas, Sentencia de 25 de octubre de 2012. Serie C No. 252, párrafo 283.

(52) Diego Chirinos, "Mitos y verdades: la Corte IDH y el indulto humanitario a Fujimori”, Diario El Comercio, 1 de febrero, sección Política, https://goo.gl/cFR6PJ (consultada el 30 de agosto de 2018).

(53) Artículo 40 de la Ley sobre el Establecimiento de Salas Extraordinarias en las Cortes de Camboya para el Procesamiento de Delitos Cometidos durante el Régimen de la Campuchea Democrática, 15 de enero de 2001.

(54) Véase Constitución Política de Colombia de 1991, artículo 150. 17 y artículo transitorio 30; Constitución Nacional de Argentina de 1994, artículo 99.5; Constitución Política de Chile de 2010, artículo 32.14; Constitución Política de Brasil de 1988, artículo 5.42 y 84.12.

(55) TC, Caso Alfredo Jalilie Awapara, Sentencia recaída en el Expediente No. 4053-2007-PHC/TC de 18 de diciembre de 2007, fundamento jurídico 24. 
Carta Magna y con tratados de derechos humanos de los que Perú es parte. Asimismo, dicho Tribunal ha afirmado lo siguiente:

"No opera la presunción de que el legislador penal ha querido actuar dentro del marco de la Constitución y el respeto de los derechos fundamentales] cuando se comprueba que mediante el ejercicio de la competencia de dictar leyes de amnistía, el legislador penal pretendió encubrir la comisión de delitos de lesa humanidad. Tampoco cuando el ejercicio de dicha competencia se utilizó para "garantizar" la impunidad por graves violaciones de derechos humanos"(56).

A partir de lo anterior, las gracias presidenciales otorgadas (indulto y derecho de gracia) resultan claramente incompatibles con el deber de investigar, juzgar y sancionar graves violaciones de derechos humanos.

\section{Resulta incompatible con el derecho a la verdad y a la tutela judicial efectiva}

El otorgar gracias presidenciales resulta una medida que puede colisionar con derechos amparados en la Constitución y protegidos por tratados de derechos humanos, que ostentan rango constitucional en nuestro ordenamiento interno ${ }^{(57)}$. En concreto, el indulto y el derecho de gracia a una persona procesada por delitos que equivalen a graves violaciones de derechos humanos puede afectar seriamente los derechos a la verdad y a la tutela judicial efectiva.

\subsection{Derecho a la verdad}

El derecho a la verdad tiene particular relevancia de cara al derecho de gracia y su aplicación en el caso Pativilca dado que se trata de hechos aún en investigación. En sus primeros casos contenciosos, la Corte IDH estableció que frente a violaciones con carácter de crímenes de lesa humanidad, "el derecho de las víctimas frente al Estado no se agota en la obtención de una compensación pecuniaria, sino que requiere una reparación integral que incluye el derecho a la justicia y al conocimiento de la verdad"(58). Este derecho se encuentra establecido expresamente en el artículo 24 de la Convención sobre Internacional para la protección de todas las personas contra las desapariciones forzadas, del cual el Perú es Estado parte. La Comisión Interamericana de Derechos Humanos (CIDH), la Corte IDH, el Alto Comisionado de la ONU para los Derechos Humanos, entre otras instancias, han afirmado que el derecho a la verdad es un derecho autónomo ${ }^{(59)}$

A nivel interno, también se le ha reconocido este carácter por parte del Tribunal Constitucional( ${ }^{(60)}$. Si bien no se encuentra expresamente consagrado en el texto constitucional, el artículo 3 establece una enumeración abierta de derechos fundamentales y permite la afirmación de derechos análogos. Con base en ello, el TC ha destacado la alta relevancia del derecho a la verdad al considerar que "(es) un derecho que se deriva directamente del principio de dignidad humana, pues el daño ocasionado a las víctimas no sólo se traduce en la lesión de bienes tan relevantes como la vida, la libertad y la integridad personal, sino también en la ignorancia de lo que verdaderamente sucedió con las víctimas de los actos criminales"(61)

En cuanto a su contenido, se ha afirmado que tiene una dimensión individual y colectiva $^{(62)}$. Su dimensión individual supone el derecho de las víctimas y sus familiares a conocer los hechos que dieron lugar a graves violaciones de los derechos humanos, así como la identidad de quienes participaron en ellos $^{(63)}$. A efectos de garantizarla, se requiere que los Estados lleven a cabo investigaciones

(56) TC, Caso Santiago Martín Rivas, Sentencia recaída en el Expediente No. 4587-2004-AA/TC de 29 de noviembre de 2005, fundamento jurídico 53.

(57) TC, Caso Colegio de Arequipa y otro, Sentencia recaída en el Expediente No. 0025-2005-PI/TC y 0026-2005-PI/TC de 25 de abril de 2006, fundamentos jurídicos 25-30.

(58) Juan E. Méndez, "Derecho a la verdad frente a las graves violaciones a los derechos humanos", en La aplicación de los tratados sobre derechos humanos en el ámbito local, comps. Víctor Abramovich, Alberto Bovino y Christian Courtis (Buenos Aires: Editores del Puerto, 1997, 522).

(59) Véase $\mathrm{CIDH}$, Derecho a la verdad en América, (Washington: CIDH, 2014). Corte IDH, Caso Myrna Mack Chang vs. Guatemala. Fondo, Reparaciones y Costas, Sentencia de 25 de noviembre de 2003. Serie C No. 101; Caso Escher y otros vs. Brasil. Excepciones Preliminares, Fondo, Reparaciones y Costas, Sentencia de 6 de julio de 2009. Serie C No. 200. Alto Comisionado de la ONU para los Derechos Humanos, Estudio sobre el derecho a la verdad, E/CN.4/2006/91, 9 de enero de 2006.

(60) TC, Caso Genaro Villegas Namuche, Sentencia recaída en el Expediente No. 2488-2002-HC/TC de 18 de marzo de 2004, fundamento jurídico 13.

(61) TC, Caso Genaro Villegas Namuche, Sentencia recaída en el Expediente No. 2488-2002-HC/TC de 18 de marzo de 2004 , fundamento jurídico 16. También ha sido reconocido por otras altas cortes de la región. Véase inter alia Corte Constitucional de Colombia, Sentencia C-715 de 2012 y Sentencia C-180/14.

(62) TC, Caso Genaro Villegas Namuche, Sentencia recaída en el Expediente No. 2488-2002-HC/TC de 18 de marzo de 2004 , fundamentos jurídicos 8-9.

(63) Véase Corte IDH, Caso Kawas Fernández vs. Honduras. Fondo, Reparaciones y Costas, Sentencia de 3 de abril de 2009. Serie C No. 196; Caso Anzualdo Castro vs. Perú. Excepción Preliminar, Fondo, Reparaciones y Costas, Sentencia de 22 de septiembre de 2009. Serie C No. 202; Caso Gelman vs. Uruguay. Fondo y Reparaciones. Sentencia de 24 de febrero de 2011. Serie C 221. 
judiciales adecuadas y efectivas para esclarecer los hechos, sancionar a las personas responsables, y reparar a las víctimas y sus familiares ${ }^{(64)}$.

Respecto a la dimensión colectiva, en palabras de la Corte Interamericana, su satisfacción "exige la determinación procesal de la más completa verdad histórica posible, lo cual incluye la determinación judicial de los patrones de actuación conjunta y de todas las personas que de diversas formas participaron en dichas violaciones y sus correspondientes responsabilidades"(65). Esta parte de que "(la) Nación tiene el derecho de conocer la verdad sobre los hechos o acontecimientos injustos y dolorosos provocados por las múltiples formas de violencia estatal y no estatal. Tal derecho se traduce en la posibilidad de conocer las circunstancias de tiempo, modo y lugar en las cuales ellos ocurrieron, así como los motivos que impulsaron a sus autores"(66). Esto le caracteriza como un bien jurídico colectivo inalienable y, en ese sentido, este derecho no solo corresponde a las víctimas y sus familiares, sino también a la sociedad en su conjunto.

En 2005, la Asamblea General de esta Organización aprobó los principios y directrices básicos sobre el derecho de las víctimas de violaciones manifiestas de las normas internacionales de derechos humanos y de violaciones graves del derecho internacional humanitario a interponer recursos y obtener reparaciones. Concretamente, el principio 24 de dicha Resolución establece que "las víctimas y sus representantes han de tener derecho a solicitar y obtener información sobre las causas de su victimización y sobre las causas y condiciones de las violaciones manifiestas de las normas internacionales de derechos humanos y de las violaciones graves del derecho internacional humanitario, así como a conocer la verdad acerca de esas violaciones"(67).

En similar sentido, la $\mathrm{CIDH}$ ha sostenido que toda la sociedad tiene el "irrenunciable derecho de conocer la verdad de lo ocurrido, así como las razones y circunstancias en las que aberrantes delitos llegaron a cometerse, a fin de evitar que esos hechos vuelvan a ocurrir en el futuro"(68). El derecho a conocer lo sucedido y de acceder a la información sobre los hechos, incluye a la sociedad en general en tanto resulta esencial para el desarrollo de los sistemas democráticos ${ }^{(69)}$. En cuanto a la información que comprende este derecho, la $\mathrm{CIDH}$ ha señalado que abarca, al menos:

“i) la conducta de quienes se hayan involucrado en la comisión de violaciones graves a los derechos humanos o el derecho internacional humanitario, especialmente en caso de masividad o sistematicidad;

ii) los elementos de carácter objetivo y subjetivo que contribuyeron a crear las condiciones y circunstancias dentro de las cuales conductas atroces fueron perpetradas e identificar los factores de índole normativa y fáctica que dieron lugar a la aparición y el mantenimiento de las situaciones de impunidad;

iii) los elementos para establecer si los mecanismos estatales sirvieron de marco a la consumación de conductas punibles;

iv) la identificación de las víctimas y sus grupos de pertenencia así como a quienes hayan participado de actos de victimización; $\mathrm{y}$

v) La comprensión del impacto de la impunidad"(70) (énfasis propio).

También ha indicado que el derecho a la verdad representa una "consecuencia básica e indispensable para todo Estado Parte en la Convención Americana (...) puesto que el desconocimiento de hechos relacionados con violaciones de los derechos humanos significa, en la práctica, que no se cuenta con un sistema de protección capaz de garantizar la identificación y eventual sanción de los responsables"(71). De este modo, el derecho a la verdad no solo es parte integral del derecho a la justicia, sino que en algunas circunstancias se hace efectivo de forma más completa

(64) CIDH, Informe 37/00, Caso 11.481, Fondo, Monseñor Oscar Arnulfo Romero y Galdámez, El Salvador, 13 de abril de 2000 , párrafo 142. Asimismo, véase Corte IDH, Caso Goiburú y otros vs. Paraguay. Fondo, Reparaciones y Costas, Sentencia de 22 de setiembre de 2006. Serie C No. 153, párrafo 165; Caso de la Masacre de Pueblo Bello vs. Colombia, Sentencia de 31 de enero de 2006. Serie C No. 140, párrafo 219.

(65) Corte IDH, Caso Gelman vs. Uruguay. Fondo y Reparaciones. Sentencia de 24 de febrero de 2011. Serie C No. 221 , párrafo 192.

(66) TC, Caso Genaro Villegas Namuche, Sentencia recaída en el Expediente No. 2488-2002-HC/TC de 18 de marzo de 2004, fundamento jurídico 8.

(67) ONU. Asamblea General, Principios y directrices básicos sobre el derecho de las víctimas de violaciones manifiestas de las normas internacionales de derechos humanos y de violaciones graves del derecho internacional humanitario a interponer recursos y obtener reparaciones, Resolución No. 60/147, aprobada el 16 de diciembre de 2005, principio 24.

(68) CIDH, Informe Anual 1985-1986, OEA/Ser.L/V/II.68, Doc. 8 rev. 1, 26 septiembre 1986, Capítulo V.

(69) Véase Corte IDH. Caso Gomes Lund y otros (Guerrilha do Araguaia) vs. Brasil. Excepciones Preliminares, Fondo, Reparaciones y Costas. Sentencia de 24 de noviembre de 2010. Serie C 219; Caso Gelman vs. Uruguay. Fondo y Reparaciones. Sentencia de 24 de febrero de 2011. Serie C 221. CIDH, Informe 136/99, Caso 10.488, Fondo, Ignacio Ellacuría y otros, El Salvador, 22 de diciembre de 1999.

(70) $\mathrm{CIDH}$, Derecho a la verdad en las Américas, (Washington: $\mathrm{CIDH}, 2014)$, párrafo 108.

(71) CIDH, Informe No. 25/98, Casos 11.505, 11.532, 11.541, 11.546, 11.549, 11.569, 11.572, 11.573, 11.583, 11.595, 11.657 y 11.705, Alfonso René Chanfeau Orayce y otros, Chile, 7 de abril de 1998, párrafo 87. 
y satisfactoria mediante procesos penales transparentes y conducidos con todas las garantías ${ }^{(72)}$.

La aplicación de las gracias presidenciales a favor de Alberto Fujimori supondría la afectación del derecho a la verdad en el caso Pativilca. La exclusión de este como procesado, considerando su calidad de Jefe de Estado y máximo jefe de las Fuerzas Armadas en la época que ocurrieron los hechos, implicaría que tanto los familiares de las víctimas como la sociedad en su conjunto no pudiesen conocer lo ocurrido en diversos extremos. Aspectos como las personas implicadas, el nivel de responsabilidad de los involucrados, entre otros, quedarían sin ser esclarecidos a través de la vía judicial. Si bien hay quienes señalaron que Fujimori podría colaborar en el proceso sin ser investigado, la Sala Penal Nacional (al decidir la aplicación de la medida en el proceso de Pativilca) señaló adecuadamente que la condición del ex Presidente era de comparecencia simple, sin restricción a su libertad(73), y que "la aplicación de la gracia presidencial en los términos que fue otorgada tendría directa vinculación a la afectación del derecho a la verdad"(74).

\subsection{Derecho a la tutela judicial efectiva}

El derecho a la tutela judicial efectiva se encuentra en el artículo 139.3 de la Constitución peruana. Tiene reconocimiento en diversos tratados de derechos humanos de los que el Perú es Estado parte. En el ámbito interamericano, por ejemplo, está protegido por los artículos 8.1 y 25.1 de la CADH, los cuales se refieren a los derechos a las garantías judiciales y la protección judicial, respectivamente. Al respecto, se ha establecido una relación por la que se dota de contenido a la obligación general de investigar las violaciones de derechos humanos; es decir, "la obligación de investigar los hechos, juzgar y, en su caso, sancionar a los responsables de un delito que constituye una violación de derechos humanos, es un compromiso que emana de la Convención Americana y la responsabilidad penal debe ser determinada por las autoridades judiciales competentes"(75).
Este derecho está vinculado al derecho a la verdad(76). La Corte IDH ha reconocido reiteradamente que el derecho de los familiares de víctimas de graves violaciones de derechos humanos a conocer la verdad se enmarca en el derecho de acceso a la justicia ${ }^{(77)}$. Igualmente, según el TC, "cobra especial relevancia ante casos de violaciones de los derechos humanos, dada su naturaleza de medio de protección de los derechos y de contradictor de la impunidad"(78).

Como ha enfatizado el TC, en virtud de este corresponde al Estado el enjuiciamiento de los responsables de graves violaciones de derechos humanos (como las ejecuciones extrajudiciales) y, si es necesario, debe adoptar medidas para evitar la impunidad. En concreto, ha considerado que:

"La aplicación de estas normas (refiriéndose a aquellas que evitan la impunidad) permite la eficacia del sistema jurídico y se justifica por los intereses prevalentes de la lucha contra la impunidad. El objetivo, evidentemente, es impedir que ciertos mecanismos del ordenamiento penal se apliquen con el fin repulsivo de lograr la impunidad. Ésta debe ser siempre prevenida y evitada, puesto que anima a los criminales a la reiteración de sus conductas, sirve de caldo de cultivo a la venganza y corroe dos valores fundantes de la sociedad democrática: la verdad y la justicia"(79).

La plena garantía de los derechos a las garantías judiciales y protección judicial busca

(72) Juan E. Méndez, "Derecho a la verdad frente a las graves violaciones a los derechos humanos", en La aplicación de los tratados sobre derechos humanos en el ámbito local, comps. Víctor Abramovich, Alberto Bovino y Christian Courtis (Buenos Aires: Editores del Puerto, 1997, 538).

(73) Además, existen mecanismos legales que regulan el caso de una persona sujeta a un proceso penal, que se encuentra padeciendo de una enfermedad, tal es el caso de los artículos 267 y 268 del Código de Procedimientos Penales y el inciso 2 del artículo 368 del Código Procesal Penal de 2004, que señalan que cuando por razones de enfermedad sea imposible la concurrencia del encausado a la sala de audiencia, el juzgamiento podrá realizarse en todo o en parte en el lugar donde este se encuentre, siempre que su estado de salud y las condiciones lo permitan.

Corte Suprema de Justicia de la República. Sala Penal Nacional, Resolución No. 039 recaída en el Expediente No 00649-2011-0-5001-JRPE-03 de 9 de febrero de 2018, 32.

(74) Corte Suprema de Justicia de la República. Sala Penal Nacional, Resolución No. 039 recaída en el Expediente Nº0649-2011-0-5001-JRPE-03 de 9 de febrero de 2018, 31 y 68.

(75) Elizabeth Salmón y Cristina Blanco, El derecho al debido proceso en la jurisprudencia de la Corte Interamericana de Derechos Humanos, (Lima: IDEHPUCP y GIZ, 2012), 28.

(76) TC, Caso Genaro Villegas Namuche, Sentencia recaída en el Expediente № 2488-2002-HC/TC de 18 de marzo de 2004 , fundamento jurídico 21 y ss.

(77) Corte IDH. Caso Bámaca Velásquez vs. Guatemala. Sentencia de 25 de noviembre de 2000. Serie C No. 70, párr. 201. Corte IDH. Caso Gomes Lund y otros (Guerrilha do Araguaia) vs. Brasil. Excepciones Preliminares, Fondo, Reparaciones y Costas. Sentencia de 24 de noviembre de 2010. Serie C No. 219, párr. 201.

(78) TC, Caso Genaro Villegas Namuche, Sentencia recaída en el Expediente N. ${ }^{\circ}$ 2488-2002-HC/TC de 18 de marzo de 2004 , fundamento jurídico 21.

(79) TC, Caso Genaro Villegas Namuche, Sentencia recaída en el Expediente N. ${ }^{\circ}$ 2488-2002-HC/TC de 18 de marzo de 2004 , fundamento jurídico 23. 
combatir la impunidad, entendida ésta como "la falta en su conjunto de investigación, persecución, captura, enjuiciamiento y condena de los responsables de las violaciones de los derechos protegidos por la Convención Americana"(80). El TC también ha señalado que las graves violaciones de derechos humanos, como la ejecución extrajudicial y la desaparición forzada, no deben quedar impunes ${ }^{(81)}$. De este modo, este derecho implica para los Estados eliminar todos los obstáculos legales y de facto que impidan el inicio y/o seguimiento de procesos judiciales en relación con graves violaciones de derechos humanos ${ }^{(82)}$.

En virtud a ello, la Corte IDH ha afirmado que los Estados deben abstenerse de recurrir a figuras como la amnistía en beneficio de los responsables, así como a alguna otra disposición análoga tales como la aplicación ilegítima de la prescripción, irretroactividad de la ley penal, cosa juzgada, ne bis in idem, la aplicación de la jurisdicción penal militar o cualquier eximente similar de responsabilidad ${ }^{(83)}$. Este es el caso también del derecho de gracia que tiene el efecto de extinguir la acción penal. En el marco de los casos Barrios Altos y La Cantuta, dicho Tribunal ha reiterado que la ejecución de sus sentencias es parte integrante del derecho al acceso a la justicia de las víctimas ${ }^{(84)}$.

Estos casos en específico, evidencian un problema de incumplimiento de las sentencias respectivas dictadas por la Corte IDH. Cabe recordar que todo Estado tiene la obligación de cumplir con el fallo internacional de manera pronta, íntegra y efectiva. La propia CADH establece expresamente en su artículo 68 el compromiso de los Estados de cumplir la decisión de la Corte y dispone garantías para lograr su cumplimiento ${ }^{(85)}$. En las sentencias de los casos Barrios Altos y La Cantuta, dicho Tribunal declaró, entre otros, la responsabilidad del Estado peruano por la falta del deber de investigar los hechos para determinar a los responsables de graves violaciones de derechos humanos, cuestión que fue desatendida con el otorgamiento del indulto en las circunstancias comentadas.

Si bien la Corte IDH no se pronunció expresamente sobre el derecho a la tutela judicial efectiva en su resolución de cumplimiento de sentencias, declaró que durante la ejecución de la pena "no se deben otorgar beneficios de forma indebida que puedan conducir a una forma de impunidad" y que "el Estado peruano no ha dado cumplimiento total a la obligación de investigar, juzgar y, de ser el caso, sancionar las graves violaciones a los derechos humanos determinadas en las sentencias emitidas"(86). Por su parte, la Sala Penal Nacional calificó al derecho de gracia como una medida que afectaba el derecho a la tutela judicial efectiva( ${ }^{(87)}$, al igual que el derecho a la verdad, en el marco del caso Pativilca.

\section{Garantías del debido proceso: debida motivación, imparcialidad y objetividad}

La CADH contempla un conjunto de derechos que condicionan el ejercicio del ius puniendi del Estado y buscan asegurar que las partes no sean sometidas a decisiones arbitrarias, toda vez que se deben observar las debidas garantías que aseguren el derecho al debido proceso ${ }^{(88)}$. Estas garantías del debido proceso no se restringen solo a procesos judiciales o penales, sino que se extienden a todo acto emanado del Estado que pueda afectar derechos $^{(89)}$. A pesar de que el artículo 8 de la CADH hace referencia a las "garantías judiciales", en virtud de lo resuelto tanto por la CIDH como por la Corte IDH en reiterada jurisprudencia, no cabe una lectura restrictiva o literal de esta disposición centrada exclusivamente en los procesos judiciales. Su interpretación debe realizarse de modo amplio

(80) $\mathrm{CIDH}$, Derecho a la verdad en las Américas, (Washington: $\mathrm{CIDH}, 2014$ ), párrafo 75.

(81) TC, Caso Genaro Villegas Namuche, Sentencia recaída en el Expediente No. 2488-2002-HC/TC de 18 de marzo de 2004 , fundamento jurídico 5 .

(82) Véase Corte IDH, Caso Barrios Altos vs. Perú, Resolución de supervisión de cumplimiento de sentencia de 7 de septiembre de 2012 , párrafo 28.

(83) Corte IDH, Caso Contreras y otros vs. El Salvador. Fondo, Reparaciones y Costas, Sentencia de 31 de agosto de 2011 . Serie C 232, párrafo 185.

(84) Corte IDH, Caso Barrios Altos y Caso La Cantuta vs. Perú. Supervisión de Cumplimiento de Sentencia, Resolución de 30 de mayo de 2018, párrafo 30.

(85) Eduardo Ferrer Mac-Gregor, coord. "Eficacia de la sentencia interamericana y la cosa juzgada internacional: vinculación directa hacia las partes ("res juficata") e indirecta hacia los estados parte de la Convención Americana ("res interpretata")", en Diálogo jurisprudencial en derechos humanos entre tribunales constitucionales y cortes internacionales. México: Tirant Lo Blanch, pp. 630.

(86) Corte IDH, Caso Barrios Altos y Caso La Cantuta vs. Perú. Supervisión de Cumplimiento de Sentencia, Resolución de 30 de mayo de 2018, párrafo 30 y parte resolutiva.

(87) Corte Suprema de Justicia de la República. Sala Penal Nacional, Resolución No. 039 recaída en el Expediente Nº0649-2011-0-5001-JRPE-03 de 9 de febrero de 2018, 68.

(88) Eduardo Ferrer Mac-Gregor, "La aplicación extensiva de las garantías judiciales penales: Un ejercicio de Derecho Comparado para el Sistema Interamericano de Derechos Humanos y México", Reforma Judicial (enero-diciembre 2016, 60).

(89) Elizabeth Salmón y Cristina Blanco, El derecho al debido proceso en la jurisprudencia de la Corte Interamericana de Derechos Humanos, (Lima: IDEHPUCP y GIZ, 2012, 84-85). 
tanto para que se apoye en el texto literal de la norma como en su espíritu(90). Así, remite a su aplicación en todas las instancias procesales $^{(91)}$, como las de tipo administrativo.

El ejercicio de las gracias presidenciales requiere que se efectúe siguiendo las garantías mínimas del debido proceso, que se derivan de la propia Constitución. A partir de su artículo 139, referido a los principios y derechos de la función jurisdiccional(92), el TC ha establecido que el debido proceso es aplicable a nivel judicial, así como "en sede administrativa e incluso entre particulares, y supone el cumplimiento de todas las garantías, requisitos y normas de orden público que deben observarse en las instancias procesales de todos los procedimientos, incluidos los administrativos y conflictos entre privados"(93).

Respecto al asunto concreto, resulta pertinente observar el cumplimiento de garantías como la imparcialidad, la objetividad y la debida motivación, las cuales son corolarios del principio constitucional de interdicción de la arbitrariedad. Más allá del contexto político en el que fue dictada la Resolución Suprema No. 281-2017JUS, se observan serias irregularidades en el cumplimiento de los requisitos estipulados en el derecho peruano para otorgar el "indulto por razones humanitarias"(94). Cuando la Corte Interamericana dispuso que el Estado peruano realizara el control constitucional respectivo, dicho Tribunal señaló que tomara en consideración aspectos como la objetividad de la Junta Médica Penitenciaria que evaluó a Fujimori, las diferencias sustanciales entre las actas médicas al respecto, el deber de motivación de la medida otorgada, y el contexto de crisis política(95). Estos elementos deben evaluarse para verificar la presencia de las referidas garantías.

\subsection{Imparcialidad y objetividad}

La Corte IDH ha determinado que las autoridades públicas que adopten decisiones que determinen derechos, aunque no sean formalmente jueces, deben cumplir con las garantías destinadas a asegurar que su decisión no sea arbitraria ${ }^{(96)}$. En esa línea, ha establecido que la garantía de imparcialidad según el artículo 8.1 de la $\mathrm{CADH}$, implica contar con la mayor objetividad posible ${ }^{(97)}$. Posee una acepción tanto subjetiva (quien interviene en una contienda particular se aproxima a los hechos de la causa careciendo, de manera subjetiva, de todo prejuicio personal), como objetiva (brindar garantías suficientes de índole objetiva que permitan desterrar toda duda que el justiciable o la comunidad puedan albergar respecto de la ausencia de imparcialidad) ${ }^{(98)}$.

Por su parte, el TC peruano también consideró que deben ofrecerse garantías suficientes de índole objetiva que permitan desterrar toda duda respecto de la ausencia de imparcialidad( ${ }^{(99)}$. En el ordenamiento interno, la Ley de Procedimiento Administrativo General establece al principio de imparcialidad como "el tratamiento y tutela igualitarios frente al procedimiento, resolviendo conforme al ordenamiento jurídico y con atención al interés general"(100). De manera más específica, el propio Reglamento Interno de la Comisión de Gracias Presidenciales establece que dicha Comisión "actúa y opina apreciando, con criterio objetivo, los elementos aportados y los obtenidos con arreglo a sus atribuciones"(101).

Como se mencionó previamente, la Junta Médica Penitenciaria que recomendó el indulto a Alberto Fujimori por razones humanitarias estuvo conformada, entre otros, por Postigo Díaz, quien había sido médico de confianza del ex mandatario desde hace veinte años y declaró su posición a favor del indulto en $2012^{(102)}$. A pesar de que el 18 de enero de 2013

(90) Juana María Ibáñez Rivas, “Artículo 8.- Garantías judiciales”, en Convención Americana sobre Derechos Humanos comentada, coords. Steiner, Christian y Patricia Uribe (México D.F.: Suprema Corte de Justicia de la Nación y KAS, 2014, 214).

(91) Véase Corte IDH, Garantías Judiciales en Estados de Emergencia (arts. 27.2, 25 y 8 Convención Americana sobre Derechos Humanos), Opinión Consultiva OC-9/87 de 6 de octubre de 1987.

(92) Artículo 139.3 de la Constitución Política del Perú.

(93) TC, Caso Mateo Grimaldo Castañeda Segovia, Sentencia recaída en el Expediente No. 04944-2011-PA/TC de 16 de enero de 2012, fundamento jurídico 12.

(94) Corte IDH, Caso Barrios Altos y Caso La Cantuta vs. Perú. Supervisión de Cumplimiento de Sentencia, Resolución de 30 de mayo de 2018, párrafo 69.

(95) Corte IDH, Caso Barrios Altos y Caso La Cantuta vs. Perú. Resolución de 30 de mayo de 2018, párrafo 69.

(96) Corte IDH, Caso del Tribunal Constitucional vs. Perú. Fondo, Reparaciones y Costas, Sentencia de 31 de enero de 2001. Serie C 71 , párrafo 71 .

(97) Corte IDH, Caso Herrera Ulloa vs. Costa Rica. Excepciones Preliminares, Fondo, Reparaciones y Costas, Sentencia de 2 de julio de 2004. Serie C 107, párrafo 171.

(98) Corte IDH, Caso Herrera Ulloa vs. Costa Rica. Sentencia de 2 de julio de 2004. Serie C No. 107, párrafo 171; Caso Atala Riffo y niñas vs. Chile. Fondo, Reparaciones y Costas, Sentencia de 24 de febrero de 2012. Serie C 239, párrafos 189 y 234.

(99) TC, Caso Luis Miguel Palomino Vargas, Sentencia recaída en el Expediente No. 04375-2015-PHC/TC de 19 de abril de 2017, fundamento jurídico 13.

(100) Numeral 1.5 del Artículo IV de la Ley No 27444, Ley de Procedimiento Administrativo General.

(101) Artículo 8 del Reglamento interno de la Comisión de Gracias Presidenciales, aprobado por Resolución Ministerial No. 0162-2010-JUS.

(102) Ernesto Cabral, "Doctor de Alberto Fujimori integra junta médica penitenciaria que pidió el indulto" 
la Comisión de Gracias Presidenciales ordenó al INPE "no aceptar la participación de médicos tratantes particulares como integrantes en la Junta Médica" con el fin de garantizar la objetividad e imparcialidad de la diligencia médica, el 12 de diciembre de 2017 el mencionado médico fue designado como miembro(103).

A los pocos días, mediante Acta de Junta Médica Penitencia de 17 de diciembre, se recomendó el indulto y derecho de gracia al expresidente, siendo acogida y elevada por la actual Comisión de Gracias Presidenciales. Más allá de las competencias del referido médico, esto pone en cuestionamiento que se encontrara en condiciones que le permitan realizar un análisis objetivo e imparcial en su calidad de autoridad o funcionario público; además, no se colige con lo establecido expresamente en su propio Reglamento.

\subsection{Debida motivación}

La debida motivación es fundamental para que un acto del poder público no sea arbitrario. Si bien una lectura literal del artículo 8 de la CADH no hace referencia a la debida motivación, la Corte IDH se ha referido al deber de motivación como una obligación inherente al artículo 8.1 de la $\mathrm{CADH}^{(104)}$. Este Tribunal ha señalado que "en toda decisión que afecte derechos humanos es fundamental la motivación de estas decisiones (...)"(105).

Asimismo, la debida motivación parte del principio constitucional de interdicción de la arbitrariedad, basado en el artículo 45 de la Constitución $^{(106)}$ y en la jurisprudencia constitucional(107). Según dicho principio, mientras más amplio es el margen de decisión que ostenta una autoridad pública, más intenso es el grado del deber de motivación de su ejercicio ${ }^{(108)}$. Igualmente, la Ley de Procedimiento Administrativo General establece que la motivación de un acto "debe ser expresa, mediante una relación concreta y directa de los hechos probados relevantes del caso específico, y la exposición de las razones jurídicas y normativas que con referencia directa a los anteriores justifican el acto adoptado"(109).

EI TC fue enfático en el caso Alfredo Jalilie Awapara al señalar que "en el otorgamiento de la gracia presidencial, deberá tomarse en cuenta la necesidad de que toda resolución suprema que disponga dicho beneficio, tenga que aparecer debidamente motivada a los efectos de que, en su caso, pueda cumplirse con evaluar su compatibilidad o no con la Constitución Política del Estado" (110). Adicionalmente, ha establecido como regla que, en estos casos, mientras mayor sea el derecho fundamental violado y mayor desprecio por el principio-derecho de dignidad humana haya relevado la conducta, mayor deberá ser la carga argumentativa y la importancia del derecho fundamental que se busca proteger con la gracia presidencial(111).

En el caso de la Resolución Suprema No. 281-2017-JUS, la decisión de otorgar la gracia presidencial no sustenta los motivos por los cuales las gracias presidenciales son concedidas, ni mucho menos fundamenta el cumplimiento de las exigencias que la propia Constitución establece para su ejercicio ${ }^{(112)}$. En la sección de consideraciones de la referida Resolución, se hace mención a las fechas y sumillas en las que se entregaron los archivos médicos que sustentarían la condición de salud de Alberto Fujimori; sin embargo, no se detallan las razones para que Kuczynski decida conceder tanto el indulto como el derecho de gracia por razones humanitarias.

La debida motivación resulta imprescindible en todo acto público, más aun cuando medida concedida tiene impacto en casos calificados como graves violaciones de derechos humanos. La Corte IDH reconoció que la carencia de motivación de la referida Resolución Suprema es un serio cuestionamiento sobre las gracias presidenciales otorgadas y, por esta razón, las autoridades jurisdiccionales peruanas deben revisar este aspecto al momento de ejercer control(113).

(103) Ernesto Cabral, "Doctor de Alberto Fujimori integra junta médica penitenciaria que pidió el indulto".

(104) Elizabeth Salmón y Cristina Blanco, El derecho al debido proceso en la jurisprudencia de la Corte Interamericana de Derechos Humanos, (Lima: IDEHPUCP y GIZ, 2012, 234-235).

(105) Elizabeth Salmón y Cristina Blanco, El derecho al debido proceso en la jurisprudencia de la Corte Interamericana de Derechos Humanos, 236.

(106) Constitución Política del Perú, Artículo 45.- El poder del Estado emana del pueblo. Quienes lo ejercen lo hacen con las limitaciones y responsabilidades que la Constitución y las leyes establecen. (...)

(107) Véase TC, Caso Adriana Betsabé Villanueva Peirano, Sentencia recaída en el Expediente No. 5760-2006-AA/TC de 19 de abril de 2007; y, Caso Jorge Samuel Chávez Sibina, Sentencia recaída en el Expediente No. 6204-2006-PHC/TC de 9 de agosto de 2006.

(108) Como explican los exmagistrados del TC, César Landa Arroyo y Ricardo Beaumont Callirgos: "la motivación del ejercicio de la gracia presidencial impide que ésta pueda ser utilizada como una 'cobertura jurídica' de actos contrarios a la Constitución y, por ende, arbitrarios". TC. Expediente No. 4053-2007-PHC/TC. Voto singular de los magistrados Landa Arroyo y Beaumont Callirgos. Párrafo 6.

(109) Numeral 6.1 del artículo 6 de la Ley 27444, Ley de Procedimiento Administrativo General.

(110) TC, Caso Alfredo Jalilie Awapara, Sentencia recaída en el Expediente No. 4053-2007-PHC/TC de 18 de diciembre de 2007, fundamento jurídico 32.

(111) TC, Caso Más de 5,000 ciudadanos c. Congreso de la República, Sentencia recaída en el Expediente No. 0012-2010-PI/TC de 11 de noviembre de 2011, fundamento jurídico 45.

(112) Luciano López Flores, "Caso Pativilca: ¿La falta de motivación anula la gracia presidencial concedida a Fujimori? Respuesta a César Nakazaki ", Legis.Pe, 15 de enero de 2018, sección Constitucional https://goo.gl/ASTWpg (consultada el 28 de agosto de 2018).

(113) Corte IDH, Caso Barrios Altos y Caso La Cantuta vs. Perú. Supervisión de Cumplimiento de Sentencia, Resolución de 30 de mayo de 2018, párrafo 69. 


\subsection{Falta de necesidad y proporcionalidad}

Aunque en el presente asunto no se encuentra acreditado el supuesto para un indulto por razones humanitarias, dado que la argumentación del Estado peruano ha consistido en sostener su existencia, presentamos algunas consideraciones a tener en cuenta incluso en el supuesto negado en que se trate de un indulto otorgado por razones humanitarias. Si bien la Corte IDH no se había pronunciado hasta entonces específicamente sobre esta figura, cuenta con un amplio acervo jurisprudencial que le permite evaluarla a partir de las obligaciones de los Estados parte de la CADH y los estándares interamericanos.

La figura del indulto humanitario buscaría, en teoría, preservar el derecho a la vida, salud e integridad de una persona privada de libertad cuya detención carcelaria representa un grave riesgo para tales derechos. Se estaría frente a un supuesto de colisión del derecho a la vida, salud e integridad, de un lado, y del derecho a la verdad y acceso a la justicia, de otro. En tal caso, la posibilidad de otorgar un indulto sin lesionar los derechos que se oponen sería legítima siempre que la aplicación del indulto humanitario se ajuste a las garantías exigidas por el DIDH para la restricción válida de derechos. Dado que se trata de una persona condenada como máximo responsable de hechos que constituyen crímenes de lesa humanidad, el escrutinio para el análisis de estas garantías debe ser sumamente estricto por la seriedad de los derechos en juego.

La Corte IDH ha abordado en diversas ocasiones la posibilidad de restringir los derechos reconocidos en la $\mathrm{CADH}$, al amparo de lo dispuesto en el artículo 30 de dicho tratado, partiendo de la afirmación de que estos no son necesariamente absolutos y en tanto, en ocasiones, su restricción permite garantizar la plena vigencia de otros derechos y valores dentro de una sociedad democrática. Sin embargo, la Corte ha sido clara en enfatizar que aquellas restricciones se encuentran sujetas a determinadas condiciones, a saber: (i) reserva de ley; (ii) objetivo legítimo; y (iii) necesaria y proporcional|(114). En el asunto bajo comentario, no se presentan tales garantías y son especialmente cuestionables aquellas referidas a la reserva de ley, necesidad y proporcionalidad.

En primer lugar, conforme a señalado la Corte IDH, "cualquier limitación o restricción debe estar prevista en la ley, tanto en sentido formal como material"(115). La ley a la que se ha referido este Tribunal es un acto normativo que busca el bien común, que ha emanado del Poder Legislativo y ha sido promulgado por el Poder Ejecutivo(116), es decir, una ley en sentido estricto. Sin embargo, en el caso del indulto humanitario concedido al ex presidente Fujimori, podemos verificar que el sustento normativo de esta decisión se encuentra en el Decreto Supremo 004-2007JUS y específicamente, en una Resolución Ministerial que aprueba el Reglamento Interno de la Comisión de Gracias Presidenciales; es decir, normas de rango infra legal que no cumplen con la exigencia de ley en sentido estricto.

De otro lado, la figura del indulto humanitario en el presente caso no es compatible con la exigencia de necesidad y proporcionalidad, requeridos para la legitimidad de la restricción de derechos. En cuanto a la necesidad, en términos de la Corte IDH, este requisito obliga a evaluar las alternativas existentes para alcanzar el fin legítimo y precisar la mayor o menor lesividad de aquellas ${ }^{(117)}$, eligiendo, como es evidente, aquella que represente una menor afectación al derecho que se restringe.

El indulto humanitario no representaba la medida menos lesiva para alcanzar el fin presuntamente perseguido, sino que existían otras alternativas menos restrictivas del derecho de acceso a la justicia de las víctimas. Si las condiciones carcelarias en las que se encontraba detenido ponían presuntamente en riesgo su salud, vida o integridad, podrían haberse adoptado medidas para mejorarlas en los términos necesarios. Podría habérsele brindado la asistencia médica necesaria dentro de las instalaciones carcelarias sin que sea necesaria su liberación o si la situación de salud lo ameritase, se le podría haber trasladado temporalmente a un centro médico. Cabe notar que las condiciones carcelarias de Alberto Fujimori eran destacables en comparación con las del promedio en Perú(118).

(114) Corte IDH. Caso Atala Riffo y niñas vs. Chile. Fondo, Reparaciones y Costas. Sentencia de 24 de febrero de 2012 . Serie C No 239 , párr. 164; Caso Tristán Donoso vs. Panamá. Excepción Preliminar, Fondo, Reparaciones y Costas. Sentencia de 27 de enero de 2009. Serie C No 193, párr. 56; Caso Escher y otros vs. Brasil. Excepciones Preliminares, Fondo, Reparaciones y Costas. Sentencia de 6 de julio de 2009. Serie C No 200, párr. 116.

(115) Corte IDH. Caso Kimel vs. Argentina. Fondo, Reparaciones y Costas. Sentencia de 2 de mayo de 2008. Serie C 177 , párrafo 63.

(116) Corte IDH. La expresión "Leyes" en el artículo 30 de la Convención Americana sobre Derechos Humanos. Opinión Consultiva OC-6/86 de 9 de mayo de 1986. Serie A 6, párr. 35

(117) Corte IDH. La expresión "Leyes" en el artículo 30 de la Convención Americana sobre Derechos Humanos. Opinión Consultiva OC-6/86 de 9 de mayo de 1986. Serie A No 6, párr. 74; Caso Chaparro Álvarez y Lapo Íñiguez vs. Ecuador. Excepciones Preliminares, Fondo, Reparaciones y Costas. Sentencia de 21 de noviembre de 2007. Serie C 170, párrafo93

(118) Según lo reportado por el diario La República en el 2012 y la BBC en el año 2013, la celda en la que se encontraba recluido Alberto Fujimori en el penal de Barbadillo contaba con un tópico, asistencia médica permanente, custodia de 17 policías, cocina, taller de pintura, huerto, sala de visitas y sala de estudio. 
Asimismo, debe reiterarse que la concesión del indulto, en los términos que fue otorgado, no solo afecta los derechos de las víctimas, sino que incumple con la obligación del Estado peruano de cumplir lo dispuesto en las sentencias sobre los casos Barrios Altos y La Cantuta. Ciertamente, en la reciente resolución de sentencia al respecto, dicho Tribunal declaró que con la medida se incumplía la obligación de investigar, juzgar y sancionar las graves violaciones de derechos humanos cometidas.

Lo anterior pone en evidencia que, dejar sin efectos la condena dictada en su contra y ponerlo en libertad considerando la gravedad de los crímenes por los que fue sentenciado, no supera el requisito de necesidad y por ello la medida resulta ilegítima.

Las etapas del test de proporcionalidad son preclusivas, por lo que deben concurrir todos los elementos para que se trate de una medida válida para el DIDH. A pesar de que no supera los aspectos anteriores, nos referimos a la proporcionalidad para advertir que tampoco se ve superada esta exigencia. En efecto, respecto a la proporcionalidad de la medida, debe analizarse si el sacrificio que supone la restricción es exagerado o desmedido frente a las ventajas que se obtienen con tal limitación ${ }^{(119)}$. La intensidad de la afectación del derecho de acceso a la justicia en el presente caso es desproporcional, pues una sentencia condenatoria con graves violaciones de derechos humanos -que además forma parte de una obligación internacional del Estado peruano- ha sido dejada sin efectos. Ello a pesar de tratarse del máximo responsable de los hechos, en tanto Jefe de Estado, quien apenas había cumplido diez de los 25 años de condena impuesta, no había pagado la reparación civil ordenada, ni había dado muestra alguna de arrepentimiento. Es más preocupante notar que estuvo ausente en la toma de la decisión toda consideración relativa a los derechos de las víctimas o la realización de una ponderación de cara a sus derechos, quienes no fueron oídas ni participaron de modo alguno en el proceso. Las víctimas no solo son actores en un juicio, sino que se vuelven actores de su propio destino y reconstrucción personal; por ello, frente a crímenes internacionales que chocan con la conciencia humana, lo más fundamental y consustancial es otorgarles una nueva vida, llena de esperanzas ${ }^{(120)}$, sin que medidas posteriores a la sentencia afecten sus derechos.

La Resolución Suprema No. 281-2017-JUS no se refirió a este punto. En el marco del SIDH, el análisis anterior fue propuesto en el amicus curiae presentado, cuyos planteamientos coincidieron en términos generales, con la postura planteada por la $\mathrm{CIDH}^{(121)}$ y el análisis de la Corte Interamericana en la resolución de supervisión de cumplimiento.
De este modo, los términos en que fue concedido el indulto y derecho de gracia resultaron abiertamente contrarios a las garantías que exige el DIDH para que se trate de una medida conforme con obligaciones internacionales en materia de derechos humanos. Representó, en suma, un acto de impunidad.

\section{Conclusiones}

Este episodio (aun inconcluso) puede conducirnos, al menos, a tres reflexiones generales en el marco del DIDH. En primer lugar, pone de manifiesto que toda autoridad pública-incluso el Presidente de la Repúblicatiene claros límites en el ejercicio de sus atribuciones, dados tanto por nuestras normas internas (Constitución, leyes), como por los tratados asumidos por el Estado peruano. Por más discrecional que sea una atribución constitucional, no implica que pueda ser ejercida arbitrariamente. En un Estado Democrático de Derecho, no es tolerable un acto que muestre desprecio por valores consustanciales a este, como justamente lo es la proscripción de la arbitrariedad. La ley, entendida en términos amplios, debe prevalecer sobre la voluntad antojadiza de los gobernantes de turno.

En segundo lugar, los asuntos de derechos humanos no son solo de interés nacional, ni mucho menos particular. La activación de una instancia internacional y los numerosos actores que condenaron la medida, son signos muy claros de su trascendencia internacional. Esto nos debe recordar que los derechos humanos son, en el mundo de hoy y desde mediados del siglo $X X$, una idea política fundamental a nivel mundial. Proveen un estándar de legitimidad moral, incorporado en las reglas de la comunidad internacional, de las que el Perú hace parte.

Tercero, en este orden internacional, los sistemas internacionales de protección de derechos son fundamentales. Este caso muestra el valor que cumple el sistema interamericano de derechos humanos para el Perú y su

(119) Corte IDH. Caso Kimel vs. Argentina. Fondo, Reparaciones y Costas. párr. 83; Caso Chaparro Álvarez y Lapo Íñiguez vs. Ecuador. Excepciones Preliminares, Fondo, Reparaciones y Costas. Sentencia de 21 de noviembre de 2007. Serie C 170, párrafo 93.

(120) Laurence Burgorgue-Larsen, "Las víctimas del delito en el proceso penal internacional: el ejemplo de la Corte Penal Internacional" en Cuadernos de política criminal $(2007,32)$.

(121) Véase $\mathrm{CIDH}$, "CIDH expresa profunda preocupación y cuestiona el indulto concedido a Alberto Fujimori”, Comunicado de Prensa https:// goo.gl/hgEdpt (consultada el 30 de agosto de 2018). 
contribución a acercarnos al ideal, consagrado constitucionalmente, de Estado Democrático de Derecho. Pero su valor no viene solo por su activación directa, mediante fallos vinculantes para el Estado, sino también por la influencia que puede ejercer la jurisprudencia interamericana en los operadores jurídicos internos. Los mecanismos activados han demostrado, hasta el momento, permitir un control de la convencionalidad y constitucionalidad de una acción arbitraria del poder público. Esperamos que el episodio culmine permitiendo consolidar este objetivo.

\section{Referencias bibliográficas}

Andreu, Federico. 2014. Artículo 3. Derecho al reconocimiento de la personalidad jurídica. En Convención Americana sobre Derechos Humanos comentada, coords. Christian Steiner y Patricia Uribe. México D.F.: Suprema Corte de Justicia de la Nación y KAS.

Burgorgue-Larsen, Laurence. 2007. Las víctimas del delito en el proceso penal internacional: el ejemplo de la Corte Penal Internacional. Cuadernos de política criminal 91: 101-124.

Burneo Labrín, José. 2017. Derecho Penal Internacional. Genealogía de los crímenes internacionales más graves. Lima: Fondo Editorial PUCP.

Cabral, Ernesto. 2017. Doctor de Alberto Fujimori integra junta médica penitenciaria que pidió el indulto. OjoPúblico, 23 de diciembre, sección Actualidad. https://goo.gl/BYgmdR (consultada el 26 de agosto de 2018).

Castro, Jonathan y Ernesto Cabral. 2017. La estrategia secreta del indulto: Los últimos días de Fujimori en la cárcel. OjoPúblico, 28 de diciembre, sección Actualidad. https://goo.gl/RFKSCz (consultada el 26 de agosto de 2018).

Chirinos, Diego. Mitos y verdades: la Corte IDH y el indulto humanitario a Fujimori. Diario El Comercio, 1 de febrero, sección Política. https://goo.gl/cFR6PJ (consultada el 30 de agosto de 2018).

Comisión Interamericana de Derechos Humanos. 1986. Informe Anual 1985-1986. OEA/Ser.L/V/II.68, Doc. 8, rev. 1. 26 de setiembre.

1998. Informe No. 25/98, Casos 11.505, 11.532, 11.541, 11.546, 11.549, 11.569, 11.572, 11.573, 11.583, 11.595, 11.657 y 11.705. Alfonso René Chanfeau Orayce y otros, Chile. 7 de abril. 2000. Informe No. 37/00, Caso 11.481, Fondo, Monseñor Oscar Arnulfo Romero y Galdámez, El Salvador. 13 de abril.

$\mathrm{CIDH}$.

2014. Derecho a la verdad en las Américas. Washington:

Comité de Derechos Humanos. 2004. Observación general No. 31: Naturaleza de la obligación jurídica general impuesta a los Estados Partes en el Pacto. CCPR/C/21/Rev.1/Add.13. 26 de mayo.

Corte Interamericana de Derechos Humanos. Caso Barrios Altos y Caso La Cantuta vs. Perú. Supervisión de Cumplimiento de Sentencia. Resolución de 30 de mayo de 2018.
Caso Anzualdo Castro vs. Perú. Excepción Preliminar, Fondo, Reparaciones y Costas. Sentencia de 22 de septiembre de 2009. Serie C, No. 202.

Caso Atala Riffo y niñas vs. Chile. Fondo, Reparaciones y Costas. Sentencia de 24 de febrero de 2012. Serie C, No. 239.

Caso Barrios Altos vs. Perú. Fondo. Sentencia de 14 de marzo de 2001. Serie C, No. 75 .

Caso Almonacid Arellano y otros vs. Chile. Excepciones Preliminares, Fondo, Reparaciones y Costas. Sentencia de 26 de setiembre de 2006. Serie C, No. 154.

. Caso Barrios Altos vs. Perú. Supervisión de Cumplimiento de Sentencia. Resolución de 7 de setiembre de 2012.

- Caso Contreras y otros vs. El Salvador. Fondo, Reparaciones y Costas. Sentencia de 31 de agosto de 2011.

Caso Gelman vs. Uruguay. Fondo y Reparaciones. Sentencia de 24 de febrero de 2011.

Caso Herrera Ulloa vs. Costa Rica. Excepciones Preliminares, Fondo, Reparaciones y Costas. Sentencia de 2 de julio de 2004.

. Caso Kawas Fernández vs. Honduras. Fondo, Reparaciones y Costas. Sentencia de 3 de abril de 2009. Serie C, No. 196.

Caso Kimel vs. Argentina. Fondo, Reparaciones y Costas. Sentencia de 2 de mayo de 2008. Serie C, No. 177.

Caso Gutiérrez Soler vs. Colombia. Sentencia de 12 de setiembre de 2005. Serie C, No. 132.

Caso La Cantuta vs. Perú. Fondo, Reparaciones y Costas. Sentencia de 29 de noviembre de 2006. Serie C, No. 162.

. Caso Masacres de El Mozote y lugares aledaños vs. El Salvador. Fondo, Reparaciones y Costas. Sentencia de 25 de octubre de 2012. Serie C, No. 252.

. La expresión "Leyes" en el artículo 30 de la Convención Americana sobre Derechos Humanos. Opinión Consultiva OC-6/86 de 9 de mayo de 1986. Serie A, No. 6.

Corte Suprema de Justicia de Chile. Sentencia de extradición a Alberto Fujimori de 5 de junio de 2017. 
Corte Suprema de Justicia de la República. Juzgado Supremo de Investigación Preparatoria. Resolución No. 006 recaída en el Expediente $\mathrm{N}^{\circ}$ 00006-2001-4-5001-SU-PE-01 de 29 de agosto de 2018.

Resolución No. 010 recaída en el Expediente No. 00006-2001-4-5001-SU-PE-01 de 3 de octubre de 2018.

. Primera Sala Penal Transitoria. Sentencia recaída en el Expediente No. 19-2001-09-A.V. de 30 de diciembre de 2009.

Sala Penal Nacional. Sentencia recaída en el Expediente No. A.V. 19-2001 de 7 de abril de 2009.

Resolución No. 039 recaída en el Expediente No. 00649-2011-0-5001-JR-PE-03 de 9 de febrero de 2018.

Sala Penal Permanente. Recurso de Nulidad No. 41042010. Ejecutoria Suprema de 20 de julio de 2012.

Defensoría del Pueblo. 2018. Indulto y derecho de gracia otorgados al expresidente Alberto Fujimori: evaluación normativa y jurisprudencial. Informe Defensorial No. 177. Lima: Defensoría del Pueblo.

2000. Derechos Humanos y Sistema Penitenciario. Supervisión de Derechos Humanos de Personas Privadas de Libertad 1998-1999. Lima: Defensoría del Pueblo.

Elías Puelles, Ricardo Nicanor. 2011. Los fines constitucionales de la pena como fundamento para la derogación de las gracias presidenciales. Tesis de licenciatura, Facultad de Derecho de la PUCP.

Ferrer Mac-Gregor, Eduardo. 2016. La aplicación extensiva de las garantías judiciales penales: un ejercicio de Derecho Comparado para el Sistema Interamericano de Derechos Humanos y México. Reforma Judicial (enero-diciembre): 57-99.

coord. 2013. Eficacia de la sentencia interamericana y la cosa juzgada internacional: vinculación directa hacia las partes ("res judicata") e indirecta hacia los estados parte de la Convención Americana ("res interpretata"). Diálogo jurisprudencial en derechos humanos entre tribunales constitucionales y cortes internacionales. México: Tirant Lo Blanch: 617-672.

Gamarra Herrera, Ronald. 2008. A propósito de la histórica extradición de Alberto Fujimori. Portal Derecho Penal de la Universidad de Fribourg. https://goo.gl/a2ZY9Z (consultada el 26 de agosto de 2018).

Ibáñez Rivas, Juana María. 2014. Artículo 8. Garantías judiciales. En Convención Americana sobre Derechos Humanos comentada, coords. Christian Steiner y Patricia Uribe. México D.F.: Suprema Corte de Justicia de la Nación y KAS.

López Flores, Luciano. 2018. "Caso Pativilca: ¿La falta de motivación anula la gracia presidencial concedida a Fujimori? Respuesta a César Nakazaki". Legis.Pe. 15 de enero, sección Constitucional, https://goo.gl/ASTWpg (consultada el 28 de agosto de 2018).

Méndez, Juan E. 1997. Derecho a la verdad frente a las graves violaciones a los derechos humanos. En La aplicación de los tratados sobre derechos humanos en el ámbito local, comps. Víctor Abramovich, Alberto Bovino y Christian Courtis. Buenos Aires: Editores del Puerto.

ONU. Asamblea General. 2005. Principios y directrices básicos sobre el derecho de las víctimas de violaciones manifiestas de las normas internacionales de derechos humanos y de violaciones graves del derecho internacional humanitario a interponer recursos y obtener reparaciones. Resolución No. 60/147, aprobada el 16 de diciembre.

Redacción Gestión. 2017. PPK: No estoy obligado a comparecer ante Comisión Lava Jato. Diario Gestión, 4 de diciembre, sección Política. https://goo.gl/naD48Y (consultada el 25 de agosto de 2018).

Redacción El Comercio. 2018. Procurador ad hoc impugnó fallo sobre Caso Pativilca. Diario El Comercio, 21 de febrero, sección Política. https://goo.gl/9XcUFS (consultada el 28 de agosto de 2018).

2017. PPK aceptó reunirse con la Comisión Lava Jato del Congreso. Diario El Comercio, 14 de diciembre, sección Política. https://goo.gl/1DDtji (consultada el 25 de agosto de 2018).

Redacción Perú21. 2017. 10 fujimoristas se abstuvieron de votar la moción de vacancia presidencial. Diario Perú21, 22 de diciembre, sección Política. https://goo.gl/rjPovD (consultada el 25 de agosto de 2018).

Relator Especial de la ONU sobre la promoción y protección del derecho a la libertad de opinión y de expresión, Frank La Rue. 2013. El derecho de acceso a la información y el derecho a la verdad, A/68/362, 4 de septiembre de 2013.

Ruiz Miguel, Alfonso. 2017. Gracia y justicia: el lugar de la equidad. Revista Derecho PUCP 79 (noviembre): $77-98$. https://doi.org/10.18800/ derechopucp.201702.004

Salmón, Elizabeth y Cristina Blanco. 2012. El derecho al debido proceso en la jurisprudencia de la Corte Interamericana de Derechos Humanos. Lima: IDEHPUCP y GIZ.

Scourfield McLauchlan, Judithanne. 2005. Congressional Participation As Amicus Curiae Before the U.S. Supreme Court. Ann Arbor: LFB Scholarly Publishing.

Tribunal Constitucional del Perú. Caso Alfredo Jalilie Awapara. Sentencia recaída en el Expediente No. 4053-2007-PHC/TC de 18 de diciembre de 2007. 
Caso Colegio de Arequipa y otro. Sentencia recaída en el Expediente No. 00252005-PI/TC y 0026-2005-PI/TC de 25 de abril de 2006.

Caso Genaro Villegas Namuche. Sentencia recaída en el Expediente No. 24882002-HC/TC de 18 de marzo de 2004.

Caso Luis Miguel Palomino Vargas. Sentencia recaída en el Expediente No. 043752015-PHC/TC de 19 de abril de 2017.

Caso Más de 5,000 ciudadanos c. Congreso de la República. Sentencia recaída en el Expediente No. 0012-2010-PI/TC de 11 de noviembre de 2011.
Caso Mateo Grimaldo Castañeda Segovia. Sentencia recaída en el Expediente No. 04944-2011-PA/TC de 16 de enero de 2012.

Caso Santiago Martín Rivas. Sentencia recaída en el Expediente No. 4587-2004-AA/TC de 29 de noviembre de 2005.

2018. Tribunal Constitucional rechaza hábeas corpus a favor del expresidente Alberto Fujimori Fujimori interpuesto contra las sentencias penales que lo condenaron por el delito de secuestro agravado en agravio de Gustavo Gorriti y Samuel Dyer. Nota de prensa. Portal del TC. https://goo.gl/wm7sQK (consultada el 28 de agosto de 2018).

Valenzuela, Carolina. 2007. "Corte Suprema resuelve extraditar a Alberto Fujimori". Diario El Mercurio, 21 de setiembre, sección Nacional. https://goo.gl/nTEqo1 (consultada el 26 de agosto de 2018). 